\title{
Kani 搪張法による骨組構造物の解法* ANALYSIS OF FRAMED STRUCTURE BY EXTENDED KANI METHOD
}

\author{
山 崎 徳 也**・太田 俊 昭*** \\ By Tokuya Yamasaki and Toshiaki Ohta
}

\section{1. 緒言}

構造物の実用解析手法としてあげられる逐次近以解法 の 1 つであるいわゆる “分配法”を大別すれば，モーメ ントを分配の対象とするものと，回転角を対象とするも のとに分けられる。前者に関しては 1930 年 H. Cross が “Analysis of Continuous Frames by Distributing Fixed-end Moment”’る論文 ${ }^{1)}$ を発表して以来, 各種 の改良が加えられ Cross 法として長足の進歩をとげた 結果, 今日に至っては各種平面ラーメンは2) とよより直 線材立体ラーメン ${ }^{3)}$ に対しても適用が可能となった。一 方後者に関しては鷹部屋教授の “挩角分配法” E. Grinter $の$ "Method of Balancing Angle Changes") が代表的なものとして有名である。その特徴を述べれば 前者の Cross 法が節点に集まる部材の材端に働くモーメ ントをすべて未知数として取り扱うのにくらべ, 後者で は節点に生ずる回転角の数に対応して平面ではわずかに 1 個, 立体の場合でも多くて 3 個の未知数を節点ごとに 考慮すれば十分であるゆえ, 明らかに未知数の数は減少 し，それだけ簡易性を増す利点を有するが，反面前者が 解析の基盤としては直接手法を取り, その算定単位とし てモーメント量を取り扱っているのに対して, 後者は変 形成分を媒分亡した間接手法であり, いわゆる変形法を 採用しているゆえ, 必然的に換算計算を行なわなければ ならず演算操作も前者の単純にくらべて必ずしも優れ ているとは断言できず，さらにその適用範囲はいまだ平 面ラーメンの領域をでず, 前者の発展にくらべてかなり 末熟な形態に止っている現状である。1949 年 G. Kani は前者のモーメントを解析の基礎単位とする方法と後者 の変形成分に立脚する解析法とを併用し, しかも両法の 長所を巧みに包含する Kani 法 ${ }^{6)}$ を提案した。すなわ ち, 回転角 $\theta$ に対応するモーメント量 $2 E K \theta$ を単位と する試索算法であり，すでに K.H. Herber ${ }^{7)}$ が指摘し たごとく第 1 にC Cross 法と比較して取り扱う未知数が 暁角分配法の場合と同様に少なくて済むこと, 第 2 は収 㪘性に優れ, 第 3 として誤差の自動的除去機構をもち, さらに第 4 として影響線解法 ${ }^{6)}{ }^{8)}$ に最適であることがあ

$*$ 昭和 38 年 5 月 第 18 回土木学会年次学術講演にて一部発 表済

** 正会員 工博 九州大学教授 工学部 土木工学教室

*** 正会員 工修 九州大学講師 工学部 土木工学教室
げられ，特に曲線部材をもつ立体ラーメンにおいて材端 モーメントを単位とする方法よりも $E K \theta$ を単位とする 方法の方が簡便さにおいて卓越することが著者らによっ て確認")されている。

また第 5 に泋角分配法との比較においても表現方法に 数段優れ, 単位換算の手間が不要であり, 特に演算操作 において後述するごとく積と加減の計算がそれぞれ別個 に行なわれ，しかも積算は被乗数が定数になっている点 でより簡明であるなど種々の利点が数えられる。

Kani 法に関する既往の研究を見るに, 適用範囲は, P. Sahmel ${ }^{10)}$ による折線部材の特殊ラーメンに関するも のを除けば, 直線材ラーメンに限られ, Cross 法と比較 して, 今日のところきわめて一般性に乏しいといえる。 そこで著者らは, 直線部材以外の部材を含むラーメン の解法へ適用しらるごとく新単位のモーメント量 $m=$ $E K \theta$ (回転成分), $M_{R}$ (部材角成分) および $M_{L}$ (伸 縮成分）を導入し，これらに基づく新しい演算法の誘導 を試み，図上表示法などにも在来の Kani 法の利点を取 り入れたうえで,さらに一般的に統一してこれを“Kani 拡張法” (Extended Kani Method) ${ }^{11)}$ と名付け, 各種 形状部材を含むラーメンの一般解法としてここに提示す るものである。

本解法の適用範囲はきわめて広く, 任意形状部材を有 する平面ラーメンを始めとして曲線材立体ラーメンに至 るまでの種々の構造物が包含されるが，それらについて 逐次検討した結果, 本解法がきわめて一般性のある実用 解法であることを確認しえた。

本論文では任意形状部材を有する平面ならびに立体ラ 一メンを対象として理論的考察を進めることとし, その 内容を任意形式のラーメンに適用可能な一般解法と, 別 に特殊なラーメン形式に便利な特殊解法とに区分し, さ らに回転成分 $m$ および部材角成分 $M_{R}$ の概算值に基 づく迅速収㪘計算法を提案して本法の収㪘性を一層高め らるよら工夫した。

\section{2. 平面ラーメンの解法}

\section{（1）定義および規約}

構成部材がすべて 1 平面内にあるようなラーメンを平 面ラーメンという（図-1 参照)。

いま 3 次元直交座標 $(x, y, z)$ の $x y$ 面内に平面ラー 
図-1
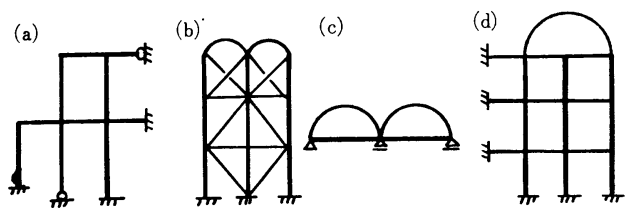

(e)
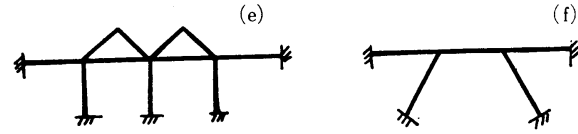

メンがあると仮定すれば, 力は $x, y$ の 2 方向に，モー メントは $z$ 軸の回りに作用する場合に限定して解析を進 めらることとなる。したがってこれらの一般力によって 生ずる変形成分も同様な関係にあり，換言すれば力に対 応して変位は $x, y$ の 2 方向に, 一方の回転角は, モ一 メントに対応して， $z$ 軸の回りに生ずることとなる。

一般にラーメンを構成する任意形状部材 $A B$ を取り 出せば, $A, B$ 端に生ずる材端 モーメントと変形成分と の関係は, 既往の平面たわみ角式 ${ }^{12)} よ り$ 次式で与えら れる。

$$
\left.\begin{array}{rl}
M_{A B}= & (\alpha m)_{A B}+(\beta m)_{B A}+\left(M_{R}\right)_{A B} \\
& +\left(M_{L}\right)_{A B}+C_{A B} \\
M_{B A}= & (\alpha m)_{B A}+(\beta m)_{A B}+\left(M_{R}\right)_{B A} \\
& +\left(M_{L}\right)_{B A}+C_{B A}
\end{array}\right\}
$$

ここに,

$$
m_{A B}=E K \theta_{A}, m_{B A}=E K \theta_{B}:
$$

材端 $A, B$ の回転成分と名付ける。 $\left(M_{R}\right)_{A B}=E K r_{A} R,\left(M_{R}\right)_{B A}=E K r_{B} R:$

材端 $A, B$ の部材角成分と名付ける。

$\left(M_{L}\right)_{A B}=E K \delta_{A} \Delta l,\left(M_{L}\right)_{B A}=E K \delta_{B} \Delta l:$

材端 $A, B$ の伸縮成分と名付ける。

また, $\alpha_{A}, \alpha_{B}, \beta_{A}, \beta_{B}, \gamma_{A}, \gamma_{B}, \delta_{A}, \delta_{B}$ : 部材形状によ って定まる定数で, 種々の形状に対する諸值を表一1に 列挙した。

\begin{tabular}{|c|c|c|c|c|c|}
\hline 非対称部材 & 对称部 林 & 円弧部材 & |放物線部材. & 对称山形部材 & 直線部 材 \\
\hline$--_{\alpha_{B}}^{\alpha_{A}}-$ & $\alpha_{A}$ & $\frac{1}{\sigma}+1+\gamma$ & 9. & 7 & 4 \\
\hline$\beta_{A}=\beta_{B}$ & $\beta_{A}$ & $\frac{1}{\sigma}-1-\gamma$ & -3 & -1 & 2 \\
\hline$\gamma_{A}=\gamma_{B}$ & $-\left(\alpha_{A}+\beta_{A}\right)$ & $-2 / \sigma$ & -6 & -6 & -6 \\
\hline$-\frac{\delta_{A}^{A}}{\delta_{B}}-$ & $\delta_{B}=-\delta_{A}$ & $-\gamma / \lambda$ & $-15 / 2 f$ & $-6 / f$ & \\
\hline$\delta_{c}$ & $\delta_{c}$ & $-\gamma / \lambda^{2}$ & $-45 / 4 f^{2}$ & $-12 / f^{2}$ & \\
\hline & $\begin{array}{l}\sin \alpha c 0 \\
\mu, \mu= \\
, f:\end{array}$ & $2 \alpha \sin ^{2} \alpha$ & & 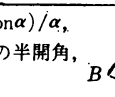 & \\
\hline
\end{tabular}

$E$ : ヤング率, $K$ : 曲げ剛度, $C_{A B}, C_{B A}$ : 材端 $A, B$ の固定端モーメント, $\theta, R, \Delta l$ : 回転角, 部材角および 部材伸縮。

\section{表一1}

なおモーメントおよび回転角の符号は, 時計回りを正 とする慣用法にしたがうものとする。

\section{(2) 節点変位のない平面構造物}

a) 基本式の誘導 節点変位がない場合は, $M_{R}=$ $M_{L}=0$ となり，したがって式 (1) より，端モーメント を求めるにはその構成要素である回転成分を決定すれば

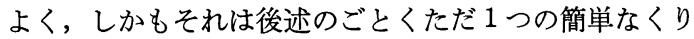
返し計算によって定められるゆえ, 問題はきわめて容易 に解決されることになる。すなわち, 構造物の任意節点 $A$ に扔いて節点方程式を立てれば,

$$
\sum_{B} M_{A B}-\bar{M}_{A}=0
$$

ただし， $\bar{M}_{A}$ は節点 $A$ に働く外力モーメントを示 す。またサフィックス $B$ は節点 $A$ に集まる部材の他 端の節点を総称するものである。

式（3）に $M_{R}=M_{L}=0$ とおいた式（1）の第 1 式を 代入して整理すれば,

$$
-\sum_{B}(\alpha m)_{A B}=\left[\sum_{B} \mathrm{C}_{A B}-\bar{M}_{A}+\sum_{B}(\beta m)_{B A}\right]
$$

ここで, $m_{A B}$ と $-\sum_{B}(\alpha m)_{A B}$ との比を考え, これ を回転係数 $\mu_{A B}$ と名付ければ, つぎのごとく剛比 $k$ に よって定められる。

$$
\mu_{A B}=-m_{A B} / \sum_{B}(\alpha m)_{A B}=-k_{A B} / \sum_{B}(\alpha k)_{A B}
$$

式 (4)，(5) よりただちに回転成分を決定する公式がえ られ次式となる。

$$
\left.\begin{array}{l}
m_{A B}=T_{A} \times \mu_{A B},(\alpha m)_{A B}=T_{A} \times(\alpha \mu)_{A B} \\
(\beta m)_{A B}=T_{A} \times(\beta \mu)_{A B}
\end{array}\right\}
$$

ただし, $T_{A}=M_{A}+\sum_{B}(\beta m)_{B A}, M_{A}=\sum_{B} C_{A B}-\bar{M}_{A}:$ 節点 $A$ の拘束成分と名付ける。

なお, 式 (5) の回転倸数の検算式には, 次式が用いら れる。

$$
\sum_{B}(\alpha \mu)_{A B}=-1
$$

b) ヒンジをもつ構造物 図一1（a）のごとくヒン ジのある構造物を対象とする場合，下記のごとき処置を 施せばこれを一貫して剛結構造物とみなして計算を進め

ることができる。すなわち，B 端がヒンジであれば， 一端ヒンジのたわみ角式を用いて $A$ 端のモーメント $\bar{M}_{A B}$ がつぎのごとく書き表わされる。ただし $M_{R}=$ $M_{L}=0$ である。

$$
\bar{M}_{A B}=(\alpha \bar{m})_{A B}+(\beta \bar{m})_{B A}+\bar{C}_{A B}
$$

ただし，

$$
\begin{aligned}
& \bar{m}_{A B}=E \bar{K} \theta_{A}, \bar{m}_{B A}=0, \\
& \bar{C}_{A B}=C_{A B}-\beta_{B A} C_{B A} / \alpha_{B A}, \bar{K}=\tau K, \\
& \tau=1-\beta_{A B} \beta_{B A} / \alpha_{A B} \alpha_{B A}
\end{aligned}
$$

したがって他端がヒンジの部材を取り扱うとき，そ の部材の剛度を $\tau K$ に置き換え, 同時にヒンジ端の 
回転成分を零として計算を進めればよい。

\section{（3）節点変位のある平面構造物}

構造物の節点が変位すれば，それに対応して部材には 図一2 のごとく部材角および部材伸縮が生ずるゆえ，こ のときの回転成分の決定式である式 (6) の $T_{A}$ は, $M_{R}$ と $M_{L}$ の影響を考慮して次式で与えられる。

$$
T_{A}=M_{A}+\sum_{B}\left(M_{R}\right)_{A B}+\sum_{B}\left(M_{L}\right)_{A B}+\sum_{B}(\beta m)_{B A}
$$

\section{図-2}
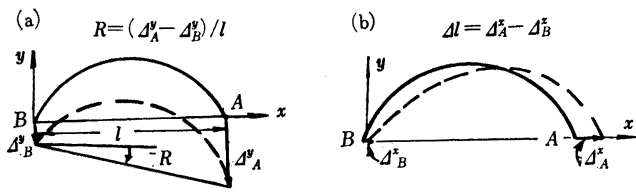

a) 部材角を有する構造物 図一3 (a), (b), (c) の ごとき水平荷重を受けて部材角を生ずる多層多スパンラ 一メンに対する考察を行ない, 部材角成分 $M_{R}$ の取り 扱い手法を略述する。

図-3

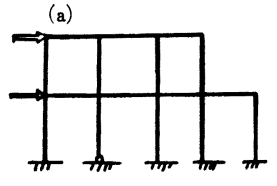

(c)

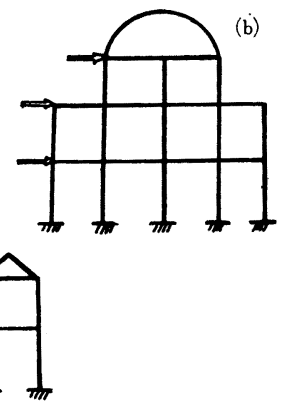

直線部材の柱のみで構成される階層 $i$ においてせん断 カのつりあい式を立てると，

$$
Q_{i}-\sum_{i j} X_{i j}=0
$$

ここに, $X_{i j}, Q_{i}$ : それぞれ柱 $i j の ~ i$ 端に働く端せん 力および階層 $i$ の上側に働く外力による階層せん断力。

いま，階層 $i$ のうち標準として選んだ柱の長さを $h_{i}$ とする。

式 (10) に $h_{i}$ を乗じた後, 換算係数 $C_{h}=h_{i} / h_{i j}$ を 用いて変形し, さらに式 (1) を代入して整理すれば結局 次式をうる。

$$
\begin{aligned}
& -\sum_{i j} C_{h} \cdot\left(M_{R}\right)_{i j} \\
= & 3\left[(\boldsymbol{M})_{i}+\sum_{i j}\left\{\left(C_{h} \cdot m\right)_{i j}+\left(C_{h} \cdot m\right)_{j i}\right\}\right]
\end{aligned}
$$

いま， $M_{R}$ の分配率ともいうべき部材角係数 $\nu_{i j}$ を つぎのごとく定義する。

$$
\begin{aligned}
\nu_{i j} & =-3\left(M_{R}\right)_{i j} / \sum_{i j} C_{h} \cdot\left(M_{R}\right)_{i j} \\
& =-3\left(C_{h} \cdot k\right)_{i j} / \sum_{i j}\left(C_{h}{ }^{2} \cdot k\right)_{i j} \cdot
\end{aligned}
$$

式 (11),(12) よりただちに $M_{R}$ に関する基本式が求 まり，次式でえられる。

$$
\left(M_{R}\right)_{i j}=\nu_{i j}\left[(\boldsymbol{M})_{i}+\sum_{i j}\left\{\left(C_{h} \cdot m\right)_{i j}+\left(C_{h} \cdot m\right)_{j i}\right\}\right]
$$

ただし， $(\boldsymbol{M})_{i}=\left\{Q_{i} h_{i}+\sum_{i j} C_{h} \cdot\left(C_{i j}+C_{j i}\right)\right\} / 6:$ 階層 $i$ の拘束成分と名付ける。

ここに, $\left(C_{h} \cdot m\right)_{i j}$ は, 式 (6) の第 1 式を $C_{h}$ 倍す ればよく，添字の $A$ を $i$ とおきつぎのごとくなる。

$$
\left.\begin{array}{l}
\left(C_{h} \cdot m\right)_{i j}=T_{i} \times\left(C_{h} \cdot \mu\right)_{i j} \\
T_{i}=M_{i}+\sum_{B}\left(M_{R}\right)_{i B}+\sum_{B}(\beta m)_{B i}
\end{array}\right\}
$$

また， $\nu_{i j}$ の検算式としては次式があげられる。

$$
\sum_{i j}\left(C_{h} \cdot \nu\right)_{i j}=-3
$$

なお，柱 $i j$ の支点 $j$ がヒンジ支承の場合は，2（2） b)に準ずれば，単に柱の長さを $\bar{h}=3 / 2 \cdot h$ に置き換える だけで剛結と見なして計算を進めることができる。

b) $M_{R}$ 補正法 一般に階層 $i$ の柱の剛比がはりの それにくらべて大きいと，その階層の $M_{R}$ はなかなか 収㪘せず，演算全体としての収㪘性がいちじるしく低下 する憾みがある。したがってかかる例に対しては, 在来 の Kani 法はもちろんのこと本法も実用価值を失う可能 性があるので，著者らはつぎのごとく $M_{R}$ 補正法を考

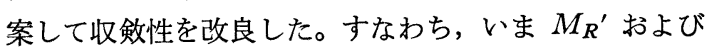
$M_{R}{ }^{\prime \prime}$ をそれぞれ $M_{R}$ の第 $n$ および第 $n+1$ 次近似值と すれば，そのときの $M_{R}$ の変化量は次式となる。

$$
\triangle M_{R}{ }^{\prime \prime}=M_{R^{\prime \prime}}{ }^{\prime \prime} M_{R^{\prime}} \quad \text { 図-4 }
$$

さて, この $\Delta M_{R}{ }^{\prime \prime}$ が項比 $\boldsymbol{r}_{i}$ の無限等比級数で変化するもの と一応仮定すれば, $M_{R}$ の補正 值は次式で求められる。

$$
M_{R}=M_{R}{ }^{\prime}+t_{i} \cdot \Delta M_{R^{\prime \prime}}
$$

ただし， $t_{i}=1 /\left(1-\boldsymbol{r}_{i}\right)$ で, 特 に $\boldsymbol{r}_{\boldsymbol{i}}$ が1にくらべて小さいと

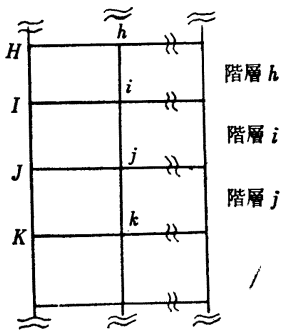
き $\left(\boldsymbol{r}_{i}<0.1\right)$ には, $t_{i} \div 1+\boldsymbol{r}_{i}$ となる。

$\boldsymbol{r}_{i}$ は階層 $i$ のすべての柱に共通であり, $M_{R}$ の第 $n$ - 1 次の変化量 $\Delta M_{R}{ }^{\prime}$ と第 $n$ 次の変化量 $\Delta M_{R}{ }^{\prime \prime}$ との 比で求められ，近似的に次式で与えられる（図-4参 照)。

$$
\boldsymbol{r}_{i}=r_{i}+r_{i h} \cdot \phi_{i h}+r_{j k} \cdot \phi_{j k}
$$

ここに,

$$
\begin{aligned}
& r_{i}=\sum_{i j}\left(C_{h} \cdot \mu_{i j}+C_{h} \cdot \mu_{j i}\right) \nu_{i j}, r_{i h}=\frac{\nu_{I J}}{\nu_{H I}} \sum_{i} C_{h} \cdot \mu_{i j} \cdot \nu_{i h} \\
& r_{j k}=\frac{\nu_{I J}}{\nu_{J K}} \sum_{i} C_{h} \cdot \mu_{j i} \cdot \nu_{j k}, \phi_{i h}=\left(\Delta M_{R}\right)_{H I} /\left(\Delta M_{R}\right)_{I J} \\
& \phi_{j k}=\left(\Delta M_{R}\right)_{J K} /\left(\Delta M_{R}\right)_{I J} \\
& \text { ただし, サフィックス } H, I, J \text { および } K \text { は, それぞ }
\end{aligned}
$$
れ各階層の最左端の節点番号を表わす。

なお，実用的には式 (17) の代りに，その第 2 項以下 を省略した $\boldsymbol{r}_{i} \doteqdot r_{i}$ を代用しても差し支えない。

c) 計算例一 1 上記誘導の基本諸式を用いて, 図一 


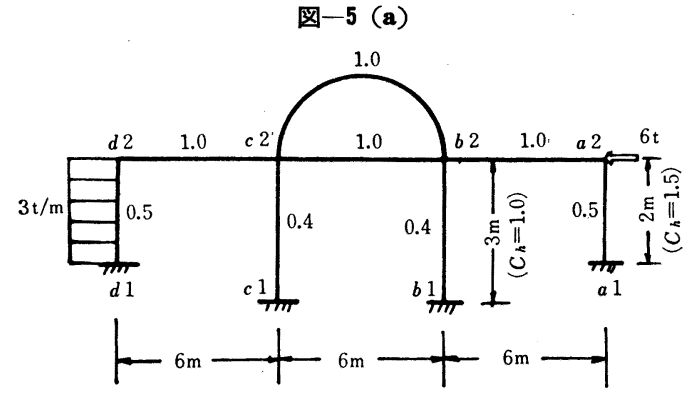

図-5 (b)

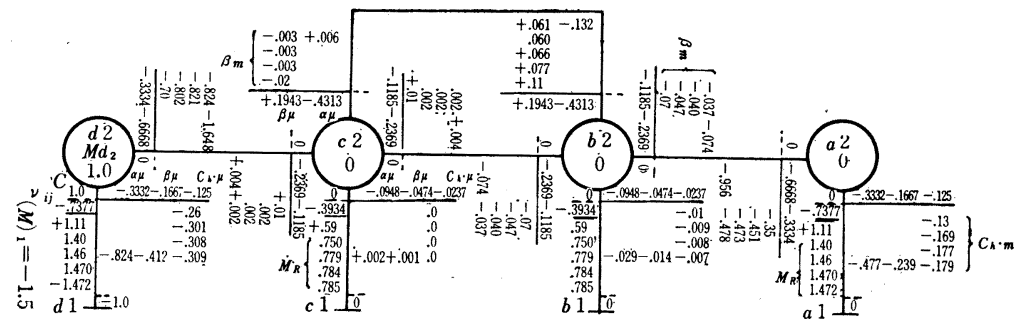

5 （a）に示す例題の演算を行なえば，以下のごとくであ る。まず準備計算として回転成分, 部材角係数および節 点ならびに階層の拘束成分を定めなければならない。す なわち, 一例として節点 $c 2$ の $\mu$ 值を求めるには，表一 1 より半開角 $\alpha=90^{\circ}$ の円弧および直線部材に対してそ れぞれ $\alpha_{A}=7.28, \beta_{A}=-3.28$ および $\alpha_{A}=4, \beta_{A}=2$ が えられるゆえ, 式 (5) に代入すれば, 所要の $\mu$ 值がつぎ のごとく算出される。

$$
\begin{aligned}
\mu_{c 2, b 2} & =\mu_{c 2, b 2}=\mu_{c 2, d 2} \\
& =-1 /(7.28 \times 1+2 \times 4 \times 1+4 \times 0.4) \\
& =-0.05924 \\
\mu_{c 2, c 1} & =-0.4 /(7.28 \times 1+2 \times 4 \times 1+4 \times 0.4) \\
& =-0.02370
\end{aligned}
$$

注） 2 節点 $A i, B j$ に円弧および直線部材がともに 連なる場合は, 特に前者を $\overparen{A i, B j}$ で後者を $\overline{A i, B j}$ で区別する。

よって $\alpha \mu, \beta \mu$ および $C_{h} \bullet \mu$ は単にこれらの值を $\alpha$, $\beta$ および $C_{h}$ 倍すればよく, 図一5(b) に示すごとくな る。つぎに 值は式 (12) を用いて,

$$
\begin{aligned}
\nu_{a_{2}, a_{1}} & =\nu_{d_{2}, d_{1}} \\
& =-3 \times 1.5 \times 0.5 / 2\left(1.5^{2} \times 0.5+1^{2} \times 0.4\right) \\
& =-0.7377 \\
\nu_{b_{2}, b_{1}} & =\nu_{c 2, c 1} \\
& =-3 \times 1.0 \times 0.4 / 2\left(1.5^{2} \times 0.5+1^{2} \times 0.4\right) \\
& =-0.3934
\end{aligned}
$$

さらに節点および階層の拘束成分がそれぞれつぎのご とく求められる。

$$
\begin{aligned}
\boldsymbol{M}_{d_{2}} & =C_{d_{2}, d_{1}}+C_{d_{2}, c_{2}}=3 \times 2^{2} / 12+0=1 \\
(\boldsymbol{M})_{1} & =\left\{Q_{1} \times h_{1}+C_{h}\left(C_{d_{2}, d_{1}}+C_{d_{1}, d_{2}}\right)\right\} \\
& =\{(2 \times 3 / 2-6) \times 3+1.5(1-1)\} / 6=-1.5
\end{aligned}
$$

かくのごとくして計算に必要なすべての数值を算定し た後, 図上計算に移るが, 図上表示法として 図一5 (b) のごとき方法を採用した。すなわち， $\alpha m, \beta m$ および $C_{h} \cdot m$ に対応する $\alpha \mu, \beta \mu$ および $C_{h} \cdot \mu$ をそれぞれ材 端において作製された欄上の空白部に書き入れるものと し，バランス計算の結果算出される $\alpha m, \beta m$ および $C_{h} \cdot m$ をこれらの $\alpha \mu-, \beta \mu-$ および $C_{h} \cdot \mu-$ 欄にそれぞ れ記入する。また固定端モーメント $C$ は材端の横の点

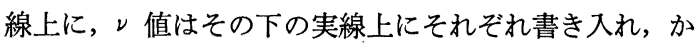
つ柱に沿って左側の空欄を $M_{R^{-}}$ 欄とする。さらに節点および階層 の拘束モーメントをそれぞれ該当 する円の内側および階層の左余白 部に適宜記入する。

かかる準備が終れば，実際にバ ランス計算に移る。まず回転成分 を零と仮定し, 式 (13) より $M_{R}$ の第 1 次近似值を求めれば,

$$
\begin{aligned}
& \left(M_{R}\right)_{a_{1}, a_{2}}=\left(M_{R}\right)_{d_{1}, d_{2}}=-1.5 \times \nu_{a_{1}, a_{2}} \doteqdot 1.11 \\
& \left(M_{R}\right)_{b_{1}, b_{2}}=\left(M_{R}\right)_{c_{1}, c_{2}}=-1.5 \times \nu_{b_{1}, b_{2}} \doteqdot 0.59
\end{aligned}
$$

つぎに節点 $d 2, c 2, b 2$ および節点 $a 2$ で式 (6), (9) および式 (14)より $\beta m, C_{h} \cdot m$ の第 1 次近似值を順次算 出する。すなわち節点 $c 2$ を例として取れば $\Sigma\left(M_{R}\right)_{A B}$ $=0.59, \Sigma(\beta m)_{B A}=-0.70+0+0=-0.70 よ り$, 式 (9) の $T_{A}$ が $T_{A}=0.59-0.70=-0.11$ と求められ, 式 (6) を用いて被乗数一定の積算，すなわち $-0.11 \times \mu$ の計算を行なえば, 結局 $\beta m$ および $C_{h} \cdot m$ が下記のご とく決定できる。

$$
\begin{aligned}
& (\beta m) \overline{c 2, b 2}=(\beta m)_{c 2, d 2}=-0.11 \times(-0.1185)=0.01 \\
& (\beta m)_{c 2, b 2}=-0.11 \times(0.1943)=-0.02 \\
& \left(C_{h} \cdot m\right)_{c 2, c_{1}}=-0.11 \times(-0.0237)=0.00
\end{aligned}
$$

さらに上記算出の $C_{h} \cdot m$ を用いて再び $M_{R}$ の第 2 次 近似值を計算する。すなわち $(\boldsymbol{M})_{1}=-1.5, \sum_{i j}\left\{C_{h} \cdot m\right)_{i j}$ $\left.+\left(C_{h} \cdot m\right)_{j i}\right\}=-0.40$ より, 式 (13) の右辺の大カッコ の值は -1.90 となる。ゆえに各柱の $M_{R}$ はそれぞれ つぎの値となる。

$$
\begin{aligned}
& \left(M_{R}\right)_{a_{1}, a_{2}}=\left(M_{R}\right)_{d_{1}, d_{2}} \doteqdot 1.40 \\
& \left(M_{R}\right)_{b_{1}, b_{2}}=\left(M_{R}\right)_{c_{1}, c_{2}} \doteqdot 0.75
\end{aligned}
$$

以上のごとき演算操作をくり返して行ない, $\beta m, C_{h}$ ・ $m$ および $M_{R}$ の各值が収束するまで続ける（図一5 (b) 参照)。

\section{d) 伸縮部材を有する構造物}

(1) 一般解法 : 伸縮部材を有する任意形式のラーメン では, 直線材ラーメンと異なり, 伸縮部材の水平反力が 加わるため，せん断力のつりあい式が伸縮部材のある階 層では直線部材で構成される階層と同一規則による同一 表現で統一できなくなり, 部材角成分および伸縮成分を 1 過程で算出することが困難となる。したがってこれら 
図-6

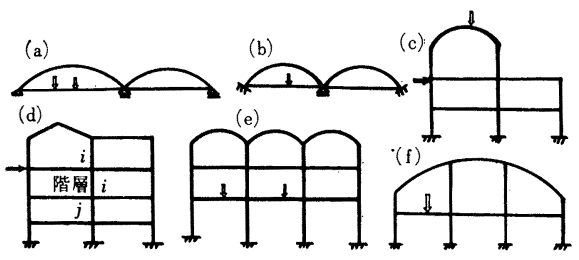

図-7

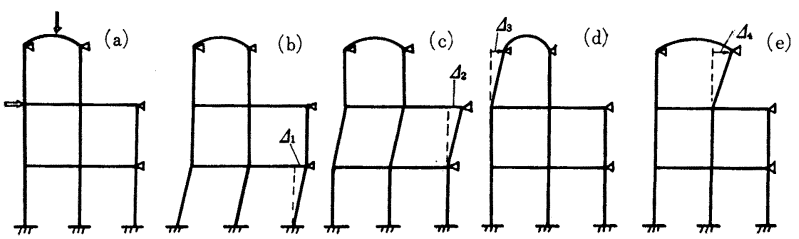

$+\sum_{B}\left(M_{L}\right)_{A B}=M_{A^{\prime}}$ も定数となる。したがって未知量で ある回転成分 $m$ が式 (6) より直ちに算定可能となる。 また一方の直線部材で構成される階層の取り扱い方は, それらの階層自身なんの拘束も受けないので，式 (9)， (6)，(14）拉よび式 (13) より $\beta m, C_{h} \cdot m$ および $M_{R}$ をそれぞれ算出でき, 結局図一8 (a), (b), (c) の各段階 におけるバランス計算は，これまでの手馿れた算出法を そのまま準用できることとなる。もちろんこの方 法でも重ね合せの法則を用いており，まず 図一8 (b), (c) の補正係数 $\omega_{1}, \omega_{2}$ を 2 本の 剛棒の軸力 が共に零でなければならないという条件よりつぎ のごとく決定する。すなわち，図一8(a)，(b) お よび (c) における剛棒の軸力をそれぞれ $N_{0}, N_{0}{ }^{\prime}$; $N_{1}, N_{1}^{\prime}$ および $N_{2}, N_{2}^{\prime}$ とすれば，補正係数 $\omega$ の成分を決定するためには，Kani 法でもCross 法と同 様にすべての節点変位の影響を個々に求めたらえで, 重 ね合せの法則にしたがって合成するといら周知の慣用法 によらなければならない。たとえば 図一6 (c) に示すラ ーメンでは, 図一7 のごとく 5 段階の計算に分けなけれ ばならず, 同種演算の回数が 5 回, さらに補正係数を求 める連立方程式が 4 元となるなど周知のごとくかなりわ ずらわしく，何らかの改良を工夫してみたくなる。かかる 見地より著者らはつぎのごとく節点の拘束条件を新しく 考案し, 上記 5 段階の分割計算を 3 段階に縮少し, 補正倸 数を求める連立方程式の元数を 2 元に短縮することを可 能ならしめた。すなわち，伸縮部材のある階層の柱の部 材角だけを拘束し, 直線部材で構成される階層の水平移 動は自由ならしめるごとくすれば，後者の階層における 柱の部材角成分は式 (13) にて算出可能となる。ゆえに 図一8 (a), (b), (c) に示すごとく“伸縮部材の両端の節 点とそれらの対角線方向にある節点との間に, 各場合に 応じて長さを加減した 2 本の両端ヒンジの剛棒を挿入す る”といら拘束手法を用られば, 伸縮部材のある階層の 柱の部材角を直線部材で構成される階層の水平移動に関 倸なく常に一定量に保つことができ, しかも両端がヒン ジであるため剛棒はモーメントのの゙ラランス計算にはなん ら関与せず，演算をいままでの方法とまったく弯わるこ となく行なうことが可能となる。すなわち, 問題の伸縮 部材のある階層では, 伸縮成分 $M_{L}$ も部材角成分 $\mathrm{M}_{R}$ もともに $\Delta_{a}, \Delta_{b}$ を定数と見做して与えるゆえ, 当然一 定值として取り扱ってよく, 式 (9)の $M_{A}+\sum_{B}\left(M_{R}\right)_{A B}$
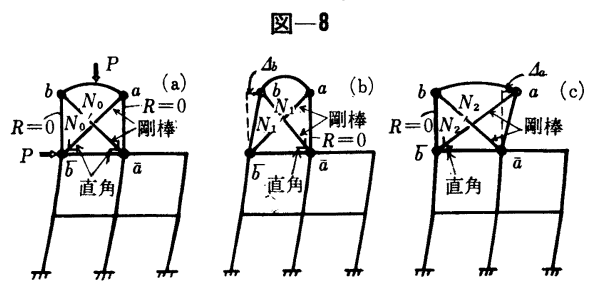

に関してつぎの連立方程式がえられる。

$$
\left.\begin{array}{l}
N_{0}+\omega_{1} N_{1}+\omega_{2} N_{2}=0 \\
N_{0}^{\prime}+\omega_{1} N_{1}^{\prime}+\omega_{2} N_{2}^{\prime}=0
\end{array}\right\}
$$

上式を連立に解けば補正係数 $\omega$ が求まり, したがっ て所要の端モーメント $M$ は, 同図 (a), (b) および (c) における端モーメントをそれぞれ $M_{0}, M_{1}$ および $M_{2}$ と するとき，重ね合せの法則より $M=M_{0}+\omega_{1} M_{1}+\omega_{2} M_{2}$ で算定される。

(2) 特殊解法 : 伸縮部材の両端の節点の相対水平变位 だけを一貫して定数とみなす一般解法の代りに，これを そのまま末知数として取り扱う方法, すなわち伸縮部材 のある階層の部材角成分および伸縮成分を算出する基本 式をあらたに導入し，ただ 1 段階の計算にて一挙にバラ ンス計算を行なわんとする解法を以下に提案する。後述 の考察にしたがえば, 本解法に必要な伸縮部材のある階 層の $M_{R}$ ならびに $M_{L}$ を決定する式はいずれも力のつ りあい式および幾何学的条件より導かれるが，これらの 条件は必然的に構造形式に支配されるゆえ, 伸縮部材の 多い構造ではそれだけ式形が複雑となり，したがって実 用性も減少することになる。それゆえここでは計算量が 節減できて，しかも簡易性を失わないで棌むごときタイ プとして図一9 (a)，(b) に示すごとき特殊な多層多スパ ンラーメンを選び，これらおのおのの場合について順次 考察を行なうことにする。

(i) 第 1 形式 : 対称伸縮部材をはりにもつ門型ラー メンをただ 1 つ最上層に有する多層多スパンの矩形ラ

\section{图一9}
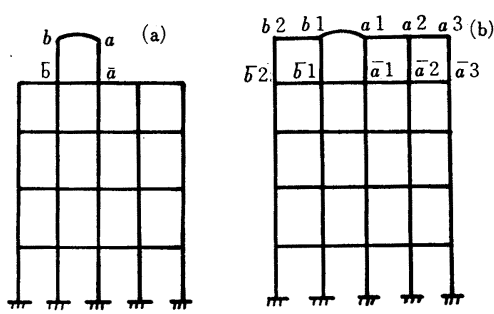
一メンを対象とするもの

で，図一9（a）がその一例 である。いまアーチの伸縮 を $\Delta l$ とすれば, 幾何学 的条件より $\Delta l=(R h)_{a \bar{a}}-$ $(R h)_{b \bar{b}}$ と表わされるゆえ， 式 (2) より 伸縮成分 $M_{L}$ はつぎのごとく簡単な $M_{R}$ の 1 次式で与えられる。

$$
\begin{aligned}
\left(M_{L}\right)_{b a}= & -\left(M_{L}\right)_{a b} \\
= & \xi_{a b}\left(M_{R}\right)_{a \bar{a}} \\
& -\xi_{b a}\left(M_{R}\right)_{b \bar{b}}
\end{aligned}
$$

図-10

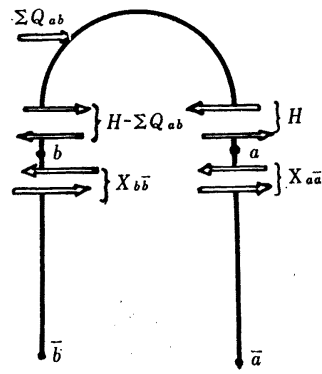

ただし，

$$
\begin{aligned}
\xi_{a b} & =\left(\gamma^{*} C_{\lambda} \cdot k\right)_{a b} / 6\left(C_{h} \cdot k\right)_{a \bar{a}} \\
\xi_{b a} & =\left(\gamma^{*} C_{\lambda} \cdot k\right)_{a b} / 6\left(C_{h} \cdot k\right)_{b \bar{b}} \\
C_{\lambda} & =h_{0} / \lambda^{*}, C_{h}=h_{0} / h, r^{*}=\delta_{A} / \zeta_{A}, \lambda^{*}=1 / \zeta_{A}, \\
\zeta_{A} & =\delta_{c} / \delta_{A}, h_{0}: \text { 標準長 }
\end{aligned}
$$

一方, 図一10に示す 2 節点 $a, b$ の力のつりあい式に式 (1) および $H=-\left(\delta_{A} m_{a b}+\delta_{B} m_{b a}\right)+\zeta_{A}\left(M_{L}\right)_{a b}+\boldsymbol{H}_{a}$ なる式を代入したうえで, これを $\left(M_{R}\right)_{a \bar{a}},\left(M_{R}\right)_{b \bar{b}}$ に ついて連立に解けば結局 $\left(M_{R}\right)_{a \bar{a}},\left(M_{R}\right)_{b \bar{b}}$ の決定公式 としてつぎなる式をうる。

\begin{tabular}{|c|c|c|c|c|c|}
\hline & 内 & & (乗数: $1 /$ 容 $\left._{a}\right)$ & & (㐘数: $1 /$ 容 $_{b}$ ) \\
\hline$D_{a}$ & $2\left(C_{h}\right)_{a \bar{a}}+2 F^{\prime}\left(C_{h}\right)_{b \bar{b}}$ & $B$ & $B^{\prime} \bar{\xi}_{b a}$ & $B^{\prime}$ & $6\left(C_{h}\right)_{b \bar{b}}$ \\
\hline$D_{b}$ & $2\left(C_{h}\right)_{b \vec{b}}+\bar{\xi}_{b a}$ & $A$ & $6\left(C_{h}\right)_{a \bar{a}}$ & $D^{\prime}$ & $\bar{r}_{b a}$ \\
\hline $\boldsymbol{C}_{\boldsymbol{a}}$ & $\begin{array}{c}h_{0}\left(\boldsymbol{X}_{a \bar{a}}-\boldsymbol{H}_{a}\right) \\
-C_{h} \cdot\left(\boldsymbol{C}_{a \bar{a}}+C_{\bar{a} a}\right)\end{array}$ & $D$ & $2 D^{\prime}\left(C_{h}\right)_{b \vec{b}}$ & $F^{\prime}$ & $\bar{\xi}_{a b}$ \\
\hline $\boldsymbol{C}_{b}$ & $\begin{array}{c}h_{0}\left(\boldsymbol{X}_{b b}+\boldsymbol{H}_{a}-\Sigma Q_{a b}\right) \\
-C_{h} \cdot\left(C_{b}+C_{b b}\right)\end{array}$ & $\overline{\boldsymbol{C}}_{a}$ & $C_{a}+F^{\prime} C_{b}$ & $\overline{\boldsymbol{C}}_{\boldsymbol{b}}$ & $\boldsymbol{C}_{b}$ \\
\hline
\end{tabular}

$$
\begin{aligned}
& \left(M_{R}\right)_{a \vec{a}}=\overline{C_{a}}-\left(B m_{b \bar{b}}+B m_{b \bar{b}}\right) \\
& -\left(A m_{a \bar{a}}+A m_{a \bar{a}}\right)+\left(D m_{a b}-D m_{b a}\right) \\
& \left(M_{R}\right)_{b \bar{b}}=\overline{\boldsymbol{C}}_{b}-\left(B^{\prime} m_{b \bar{b}}+B^{\prime} m_{\bar{b} b}\right) \\
& +\left(D^{\prime} m_{b a}-D^{\prime} m_{a b}\right)+F^{\prime}\left(M_{R}\right)_{a \bar{a}}
\end{aligned}
$$

ただし式 (19), (20) の係数 $A, B, \cdots, F^{\prime}$ および荷重 に関する項 $\bar{C}$ は，それぞれ表一2 に示す内容をもつ。

表-2

ただし $\bar{\xi}=\xi C_{\lambda}, \bar{r}=r^{*} C_{\lambda}, \boldsymbol{X}$ : 荷重による柱の端せん力 $\Sigma Q_{a b}:$ アーチ部材 $a b$ に働く水平荷重 $\boldsymbol{H}_{a}:$ 材端 $\boldsymbol{a}$ に働く固定水平反力

ここに, $A m, B m, B^{\prime} m, D m$ および $D^{\prime} m$ は, いず れも式 (6) の第 1 式をそれぞれ $A, B, B^{\prime} D$ および $D^{\prime}$ 倍した ものであり，したがってそれぞ れに対応して, $A \mu, \cdots, D^{\prime} \mu$ を あらかじめ求めておき，各節点 で $\beta m$ を決定する際に被乗数 一定の積算でこれらを同時に定 めることができわざわざ別途に
算出する必要はない。一般に伸縮部材を有する階層の柱 の $M_{R}$ は非常に収㪘が悪く, したがって 2. (3) b) と同 じく等比級数による補正を行なって収㪘性を改良する必 要がある。すなわち, 問題の $M_{R}$ の変化率が $\boldsymbol{r}$ で変化す ると仮定すれば， $M_{R}$ の補正值は式 (16) を用いて求め ればよく, その際の項比はバランス計算の操作手順の規 則性より近似的に求まるが, 紙面の都合上誘導過程を省 略し，結果のみをつぎに示す。

$$
\left.\begin{array}{l}
\left(M_{R}\right)_{a \bar{a}} \text { に関して: } \boldsymbol{r}_{a}=r_{a}+r_{a b} \phi_{b} \\
\left(M_{R}\right)_{b \bar{b}} \text { に関して }: \boldsymbol{r}_{b}=r_{b}+r_{b a} \phi_{a}
\end{array}\right\}
$$

ここに,

$$
\begin{aligned}
& \phi_{b}=1 / \phi_{a}=\left(\Delta M_{R}\right)_{b \bar{b}} /\left(\Delta M_{R}\right)_{a \bar{a}} \\
& p_{0}=D\left(\mu_{b a}+\mu_{a b}\right), q_{0}=D^{\prime}\left(\mu_{a b}+\mu_{b a}\right)-B^{\prime} \mu_{b \bar{b}} \\
& r_{a}=-A\left(\mu_{a \bar{a}}+\mu_{a \bar{a}}\right)-p_{0} \xi_{a b} \\
& r_{b}=r_{a b} F^{\prime}-B^{\prime}\left(\mu_{b \bar{b}}+\mu_{b \bar{b}}\right)-q_{0} \xi_{b a} \\
& r_{a b}=-B\left(\mu_{b \bar{b}}+\mu_{b \bar{b}}\right)+p_{0} \xi_{b a}, r_{b a}={ }_{r a} F^{\prime}+q_{0} \xi_{a b}
\end{aligned}
$$

(ii) 第 2 形式 : 本形式では 図一-9 (b) のごとく最上 層に 1 つの対称伸縮部材を含む多層多スパンラーメンを 対象とする。本形式の $M_{R}$ および $M_{L}$ も第 1 形式と同 様に導かれ，それぞれ次式となる。 $M_{L}$ については，

$$
\begin{aligned}
\left(M_{L}\right)_{b_{1}, a_{1}}= & -\left(M_{L}\right)_{a_{1}, b_{1}}=\xi_{a_{1}, b_{1}}\left(M_{R}\right)_{a_{1}, \overline{a_{1}}} \\
& -\xi_{b_{1}, a_{1}}\left(M_{R}\right)_{b_{1}, \overline{b_{1}}} \ldots \ldots \ldots \ldots \cdots \cdots
\end{aligned}
$$

ただし，

$$
\begin{aligned}
& \xi_{a_{1}, b_{1}}=\left(\gamma^{*} C_{\lambda} \cdot k\right)_{a_{1}, b_{1}} / 6\left(C_{h} \cdot k\right)_{a_{1}, \widehat{a_{1}}} \\
& \xi_{b_{1}, a_{1}}=\left(\gamma^{*} C_{\lambda} \cdot k\right)_{a_{1}, b_{1}} / 6\left(C^{\lambda} \cdot k\right)_{b_{1}, \bar{b}_{1}}
\end{aligned}
$$

つぎに最上層の柱の $\left(M_{R}\right)_{a i}, \bar{a} i$ および $\left(M_{R}\right)_{b i, \overline{b i}}$ は $\left(M_{R}\right)_{a_{1}, \overline{a_{1}}}$ および $\left(M_{R}\right)_{b_{1}, \overline{b_{1}}}$ を用いてそれぞれつぎの ごとく一般表示できる。

$$
\left.\begin{array}{l}
\left(M_{R}\right)_{a i, \bar{a} i}=\eta_{a i}\left(M_{R}\right)_{a_{1}, \overline{a_{1}}} \\
\left(M_{R}\right)_{b i, \bar{b} i}=\eta_{b i}\left(M_{R}\right)_{b_{1}, \overline{b_{1}}}
\end{array}\right\}
$$

$$
\text { ただし, } \begin{aligned}
\eta_{a i} & =\left(C_{h} \cdot k\right)_{a i}, \overline{a i} /\left(C_{h} \cdot k\right)_{a_{1}, \overline{a_{1}}} \\
& \eta_{b i}=\left(C_{h} \cdot k\right)_{b i, \overline{b i}} /\left(C_{h} \cdot k\right)_{b_{1}, \overline{b_{1}}}
\end{aligned}
$$

また所要の $\left(M_{R}\right)_{a_{1}, \overline{a_{1}}},\left(M_{R}\right)_{b_{1}, \overline{b_{1}}}$ の決定式は次式と なる (表一3 参照)。

$$
\begin{aligned}
& \left(M_{R}\right)_{a 1}, \bar{a} \overline{1}=\overline{\boldsymbol{C}}_{a}-\sum_{i}\left(B_{i} m_{b i, \overline{b i}}+B_{i} m_{b i, \overline{b i}}\right) \\
& \quad-\sum_{i}\left(A_{i} m_{a i, \bar{a} i}+A_{i} m_{a i, \bar{a} i}\right) \\
& +\left(D m_{a_{1}, b_{1}}-D m_{b_{1}, a_{1}}\right)
\end{aligned}
$$

$$
\left.\begin{array}{l}
\left(M_{R}\right)_{b_{1}, \overline{b 1}}=\overline{\boldsymbol{C}}-\sum_{i}\left(B_{i}^{\prime} m_{b i, \overline{b i}}+B_{i}{ }^{\prime} m_{b i, \overline{b i}}\right) \\
+\left(D^{\prime} m_{b_{1}, a_{1}}-D^{\prime} m_{a_{1}, b_{1}}\right)+F^{\prime}\left(M_{R}\right)_{a_{1}, \overline{a_{1}}}
\end{array}\right\}
$$

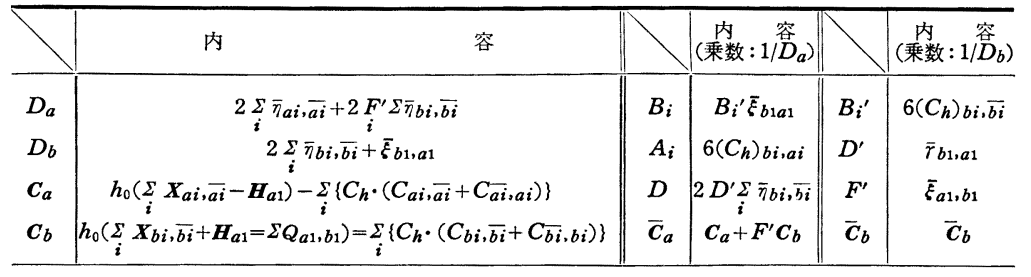

ただし $\bar{\eta}=\eta C_{\lambda}$ 
さらに $\left(M_{R}\right)_{a_{1}, \overline{a_{1}}},\left(M_{R}\right)_{b_{1}, \overline{b_{1}}}$ の項比は下記の式で与 えられる。

$$
\boldsymbol{r}_{a_{1}}=r_{a_{1}}+r_{a_{1}, b_{1}} \phi_{b_{1}}, \boldsymbol{r}_{b_{1}}=r_{b_{1}}+r_{b_{1}, a_{1}} \phi_{a_{1}} \cdots
$$

ただし，

$$
\begin{aligned}
\phi_{b_{1}} & =1 / \phi_{a_{1}}=\left(\Delta M_{R}\right)_{b_{1}, \overline{b_{1}}} /\left(\Delta M_{R}\right)_{a_{1}, \overline{a_{1}}} \\
r_{a_{1}} & =-\sum_{i} A_{i}\left(\mu_{a i}, \overline{a i}+\mu_{a i}, \overline{a i}\right) \eta_{a i}-p_{0} \xi_{a_{1}, b_{1}} \\
r_{a_{1}, b_{1}} & =-\sum_{i} B_{i}\left(\mu_{b i, \overline{b i}}+\mu_{b i, \bar{b}}\right) \eta_{b i}+p_{0} \xi_{b_{1}, a_{1}} \\
r_{b_{1}} & =r_{a_{1}, b_{1}} F^{\prime}-\sum_{i} B_{i}{ }^{\prime}\left(\mu_{b i, \overline{b_{1}}}+\mu_{b i, \overline{b i}}\right) \eta_{b_{i}}-q_{0} \xi_{b_{1}, a_{1}} \\
r_{a_{1}, b_{1}} & =r_{a_{1}} F^{\prime}+q_{0} \xi_{a_{1}, b_{1}}, p_{0}=D\left(\mu_{b_{1}, a_{1}}+\mu_{a_{1}, b_{1}}\right) \\
q_{0} & =D^{\prime}\left(\mu_{b_{1}, a_{1}}+\mu_{a_{1}, b_{1}}\right)-B_{1}^{\prime} \mu_{b_{1}, \bar{b}_{1}}
\end{aligned}
$$

\section{（4）概算值に基づく迅速収㪘計算法}

以上述べたバランス計算法では, 演算を回転成分 $m$ の算出より始めるとき, 最初に選んだ節点 $A$ において まず他端 $B$ の $m_{B A}$ をすべて零に仮定して, ただ $\boldsymbol{M}_{A}$ のみを単純に式 (6) に代入して $m_{A B}$ の第 1 次近似值 を算定してきた。また演算を $M_{R}$ の算出より始めると きでもすべての $m$ を零として，その階層の拘束成分の みを式 (13) に代入して， $M_{R}$ の第 1 次近似值を求める というごとくきわめて素朴に公式的な取り扱い方しか行 なっていない。一般に逐次近似法の収㪘度の良し悪しは 最初に用いる近似值がいかに最終収斂值に近いかによっ て定まるといってよく, 近ければ近いほど収㪘は短時間 のうちに終了し，それだけ演算の手間が省けるのでかか る点を改良発展させることはきわめて重要な意義をも つ。K.H. Herber ${ }^{7)}$ や P. Sahmel ${ }^{13)}$ らは, 節点荷重 を受ける部材のモーメント分布が近似的に反対称の直線 分布をなすといら観点に基づいて各成分の概算値を求め ている。しかしこの方法は直線材対称ラーメンや平行弦 フィーレンディール桁などの特殊なラーメンにしか有効 でなく，したがってイテラチオン法の根本原理に基づい たもっと普遍的な概算值推定法が工夫さるべきである。

著者らはかかる見地より等比級数を用いて第 1 次近似值 に対する概算値の理論的推定を行ない。本法の威力を倍 加せんことを企図し，つぎのごとき概算值推定法を提案 する。

a) 節点変位のない構造物に対する概算值推定法 構 造物の節点 $A$ における拘束成分を $\boldsymbol{M}_{\boldsymbol{A}}$ とすれば，バ ランス計算によって部材 $A B$ の $A$ 端には $m_{A B}$ が配 分され，同時に他端 $B$ にはこの $m_{A B}$ を $\beta_{A}$ 倍したモ 一メント量が伝達される。すなわち $(\beta m)_{A B}$ が節点 $B$ の拘束成分として新しく受け入れられる。しかるにこの 量は節点 $B$ で同じく $(\beta \mu)_{B A}$ 倍されて再び節点 $A$ に $M_{A}$ の補正量として戻ってくる。以上のごとき演算回路 を一巡した結果求められる補正量 $\Delta \boldsymbol{M}_{\boldsymbol{A}}$ 浽他端 $B$ が複 数個ある一般的な場合を想定すれば，式 (6) の第 3 式よ り次式で与えられる (図一11 参照)。

$$
\Delta \boldsymbol{M}_{A}=\left\{\sum_{B}(\beta \mu)_{A B}(\beta \mu)_{B A}\right\} \boldsymbol{M}_{A}
$$

ここで, $\Delta \boldsymbol{M}_{A}$ と $\boldsymbol{M}_{A}$ との比を $\boldsymbol{r}_{A}$ とすれば，つぎ

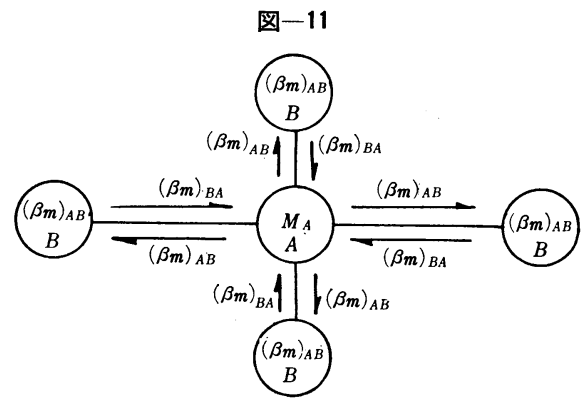

のごとき定数となる。

$$
\boldsymbol{r}_{A}=\sum_{B}(\beta \mu)_{A B}(\beta \mu)_{B A}
$$

特に図一6 (a), (b) のごとく2 節点間に直線部材と伸 縮部材の 2 部材がある場合は, 前者の $\beta \mu$ を $(\beta \mu) \overline{A B}$ 後 者のそれを $(\beta \mu) \widehat{A B}$ とすれば，

$$
r_{A}=\sum_{B}\{(\beta \mu) \overline{A B}+(\beta \mu) \widehat{A B}\}\{(\beta \mu) \overline{B A}+(\beta \mu) \widehat{B A}\}
$$

収㪘に至るバランス計算は理論的には上記演算回路を 無限回くり返えすことに他ならず，したがって $\Delta \boldsymbol{M}_{\boldsymbol{A}}$ の 変化率 $\boldsymbol{r}_{A}$ は近似的に無限等比級数の項比と考えること

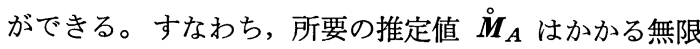
級数の級数和として求められ次式で与えられる。

$$
\stackrel{\circ}{M}_{A}=S_{A}=t_{A} \boldsymbol{M}_{A}, t_{A}=1 /\left(1-\boldsymbol{r}_{A}\right) \text {. }
$$

実態に即応した他端 $B$ に拘束成分 $\boldsymbol{M}_{B}$ が存在する ごとき一般載荷状態を考慮するときは, 式 (29) はつぎ のごとくなる。

$$
\stackrel{\circ}{\boldsymbol{M}}_{A}=S_{A^{\prime}}=t_{A}\left[\boldsymbol{M}_{A}+\sum_{B}(\beta \mu)_{B A} \boldsymbol{M}_{B}\right]
$$

よってかかる $\boldsymbol{M}_{A}$ に対する回転成分の概算值 $[m]$ お よび $[\beta m]$ は，それぞれ式 (6) より次式で算出される。

$$
[m]_{A B}=\stackrel{\circ}{M}_{A} \cdot(\mu)_{A B},[\beta m]_{A B}=\check{M}_{A} \cdot(\beta \mu)_{A B}
$$

b) 節点変位のある構造物に対する概算值推定法 図 -12 のごときラーメンの直線部材で構成される階層 $i$ の拘束成分を $(\boldsymbol{M})_{i}$ とすれば，乙れは各柱に部材角係数 $\nu_{i j}$ の割合でそれぞれ部材角成分 $\left(M_{R}\right)_{i j}$ として分配さ れ，式 (13) より $\nu_{i j}(\boldsymbol{M})_{i}$ で与えられる。しかるにこ の部材角成分は節点 $i, j$ にそのまま提供され，ひいては 階層 $i$ の上下寸べての節点に回転成分 $m_{i j}$ および $m_{j i}$ を，したがって $\left(C_{h} \cdot m\right)_{i j}$ および $\left(C_{h} \cdot m\right)_{j i}$ を生ずる 原因となり，再びこれらの $C_{h} \cdot m$ があらためて階層 $i$ の 拘束成分の補正量 $(\Delta \boldsymbol{M})_{i}$ を誘発させる。すなわち， $\Delta(\boldsymbol{M})_{i}$ は $\Delta(\boldsymbol{M})_{i}=(\boldsymbol{M})_{i} \sum_{i j}\left\{\left(C_{h} \cdot \mu\right)_{i j}+\left(C_{h} \cdot \mu\right)_{j i}\right\} \nu_{i j}$ と 図-12

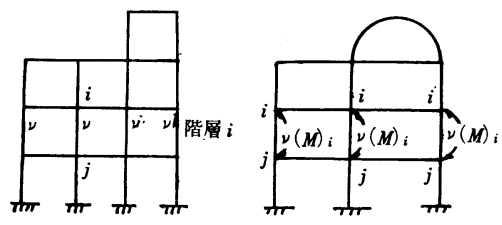


なる。よって $\Delta(\boldsymbol{M})_{i}$ と $(\boldsymbol{M})_{i}$ との比を 2. (4)a) と同様に項 比 $\boldsymbol{r}_{\boldsymbol{i}}$ で定義すればつぎのごと く求められる。

$$
\begin{aligned}
\boldsymbol{r}_{\boldsymbol{i}}= & \Delta(\boldsymbol{M})_{i} /(\boldsymbol{M})_{i} \\
= & \sum_{\boldsymbol{i} j}\left\{\left(C_{h} \cdot \mu\right)_{i j}\right. \\
& \left.+\left(C_{h} \cdot \mu\right)_{j i}\right\} \nu_{i j} \cdots(32)
\end{aligned}
$$

したがって所要の $(\boldsymbol{M})_{i}$ の 推定值 $(\stackrel{M}{\boldsymbol{M}})_{i}$ は, 同じく級数和 $\left(S_{i}\right)$ で与えられ次式となる。

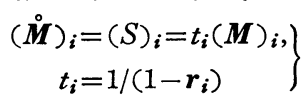

ゆえにこの推定值に基づく部 材角成分の概算値は，回転成分 ならびに伸縮成分を零として式 (13)より次式で与えられる。

$$
\left[M_{R}\right]_{i j}=\nu_{i j}(\stackrel{\circ}{\boldsymbol{M}})_{i} \cdots(34)
$$

一方, 節点 $A$ の拘束成分の 推定值 $\dot{M}_{A}$ は, $\left[M_{R}\right]$ の影響 を加味すればつぎの式で求めら れる。

$$
\begin{aligned}
\stackrel{\circ}{\boldsymbol{M}}_{A}= & S_{A}+\sum_{B}\left[M_{R}\right]_{A B} \\
& +\sum_{B}[\beta m]_{B A} \cdots
\end{aligned}
$$

ゆえにこの推定值 $\stackrel{\circ}{M}_{A}$ に基 ゔく $m, \beta m$ および $C_{h} \cdot m$ の 概算值 $[m],[\beta m]$ および $\left[C_{h}\right.$ • $m]$ は，それぞれ式 (6),(14)よ り次式で決定される。

$$
\begin{gathered}
{[m]_{A B}=\stackrel{\circ}{M}_{A} \times \mu_{A B},} \\
{[\beta m]_{A B}=\stackrel{\circ}{M}_{A} \times(\beta \mu)_{A B},}
\end{gathered}
$$$$
\left[C_{h} \cdot m\right]_{A B}=\dot{M}_{A} \times(C h \cdot \mu)_{A B}
$$

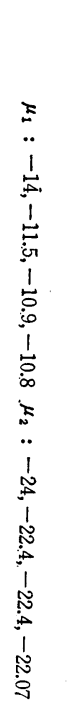

$$
\mu_{1}^{\circ}=2 E(-12.4)
$$$$
\mu_{2}^{\circ}=2 E(-27)
$$$$
\varphi_{1}{ }^{\circ}=2 E(3.9)
$$$$
\varphi_{2}^{\circ}=2 E(3.3)
$$$$
0.3333
$$

図一13（b） Kani 拡 腲 法

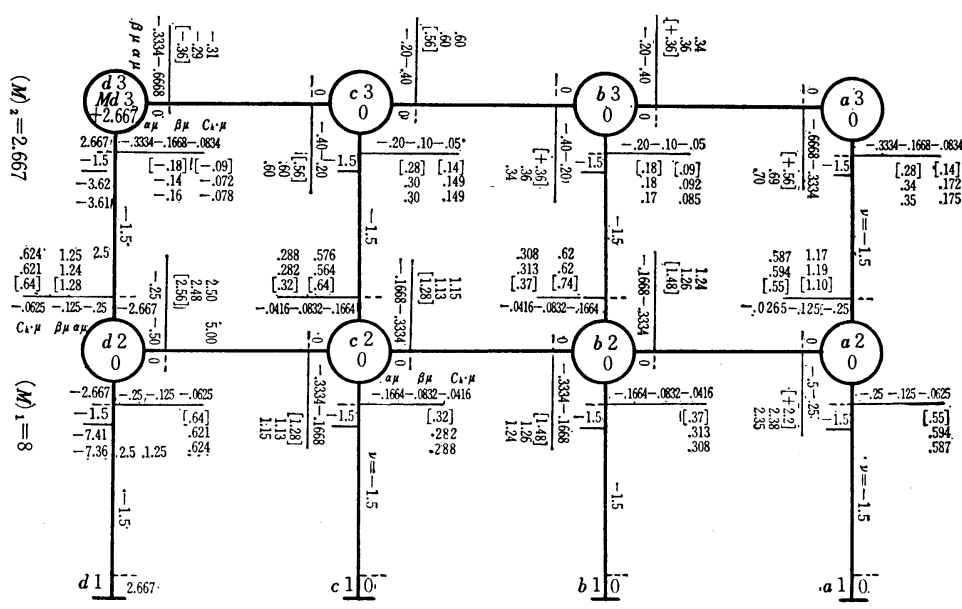

図一13 (c) 接角分配法

$$
\begin{array}{ll}
\varphi_{3}{ }^{\circ}=2 E(3.3) & \varphi_{7}{ }^{\circ}=2 E(1.4) \\
\varphi_{4^{\circ}}=2 E(4.4) & \varphi_{8}{ }^{\circ}=2 E(0.24) \\
\varphi_{5}{ }^{\circ}=2 E(2.1) &
\end{array}
$$$$
\varphi_{6}{ }^{\circ}=2 E \text { (1.4) }
$$

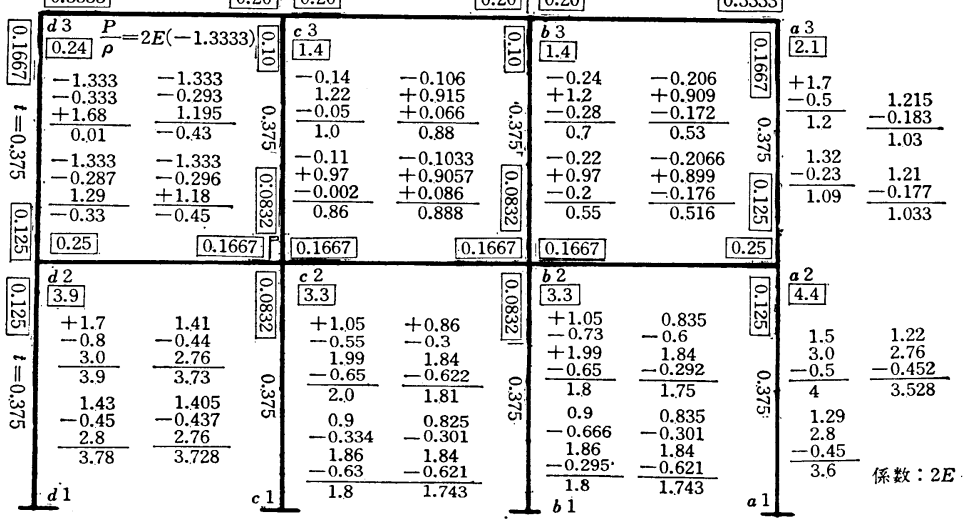

ここに, 式 (35) の右辺の第 3 項 $\Sigma[\beta m]_{B A}$ は, す でに算出された他節点 $B$ における $\beta m$ の概算值の和 であり，いまだ算出されていない節点での $[\beta m]_{B A}$ は 拘束成分 $\boldsymbol{M}_{\boldsymbol{A}}$ がある場合は $t_{A} \boldsymbol{M}_{B}(\beta \mu)_{B A}$ とし，ない 場合は零と仮定する。

c) 計算例一2 図一13(a) に示す 2 層 3 スパンのラー

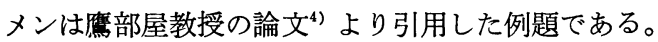

(i) 準備計算: 計算に必要な諸係数 $\mu, \alpha \mu, \beta \mu, C_{h} \cdot \mu$ 図-13 (a)

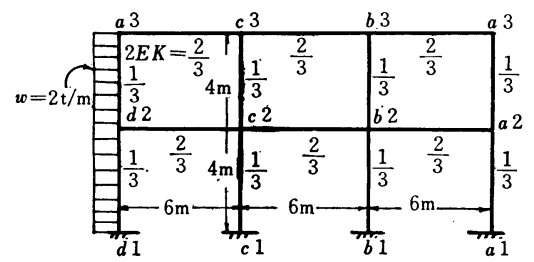

およびレをそれぞれ式 (5) および式 (12) より算出すれ ば図一13(b) に示すごとくなる。また荷重に関する拘束 成分は，第 1 ，第 2 階層で式（13）よりそれぞれ，

$$
\begin{aligned}
& (\boldsymbol{M})_{1}=\left\{3 w h^{2} / 2+1.0\left(w h^{2} / 12-w h^{2} / 12\right)\right\} / 6=8 \\
& (\boldsymbol{M})_{2}=\left\{w h^{2} / 2+1.0\left(w h^{2} / 12-w h^{2} / 12\right)\right\} / 6=2.667
\end{aligned}
$$

となり,さらに節点の拘束成分は式 (6) より,

$$
\boldsymbol{M}_{d_{2}}=w h^{2} / 12-w h^{2} / 12=0, \boldsymbol{M}_{d_{3}}=w h^{2} / 12=2.667
$$

上記算出の $(\boldsymbol{M})_{1},(\boldsymbol{M})_{2}$ および $\boldsymbol{M}_{d_{3}}$ を用いて各成分 の推定值ならびに概算值を算定すればそれぞれ以下のご とく求められる。

第 1 ，第 2 階層の $\boldsymbol{r}, t$ を式 (32), (33) によって求め れば,

$$
\boldsymbol{r}_{1}=0.156, \boldsymbol{r}_{2}=0.356, t_{1}=1.185, t_{2}=1.553
$$

また節点 $d 3$ の $\boldsymbol{r}, t$ については, 式 $(28 \mathrm{a}),(29)$ よ りつぎの值をうる。

$$
\boldsymbol{r}_{d_{3}}=0.088, t_{d_{3}}=1.095
$$


以上から階層の拘束成分を推定するには式 (33) を, 節点 $d 3$ の $S_{d_{3}}$ を求めるには式 (29) を用いればよく それぞれつぎの值となる。

$$
\begin{aligned}
& \left(\stackrel{\text { M }}{)_{1}}{ }_{1}=1.185 \times 8 \fallingdotseq 9.48\right.
\end{aligned}
$$

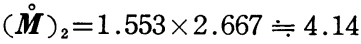

$$
\begin{aligned}
& S_{d_{3}}=1.095 \times 2.667 \doteqdot 2.92
\end{aligned}
$$

つぎにこれらの推定值を用いて $M_{R}$ および $m$ の概 算值を逐次算定する。まず $M_{R}$ の概算值を求めれば式 (34)より,

$$
\begin{aligned}
{\left[M_{R}\right]_{a_{2}, a_{1}} } & =\left[M_{R}\right]_{b_{2}, b_{1}}=\left[M_{R}\right]_{c_{2}, c_{1}} \\
& =\left[M_{R}\right]_{d_{2}, d_{1}}=-0.75 \times 9.48=-7.11 \\
{\left[M_{R}\right]_{a_{3}, a_{2}} } & =\left[M_{R}\right]_{b_{3}, b_{2}}=\left[M_{R}\right]_{c_{3}, c_{2}} \\
& =\left[M_{R}\right]_{d_{3}, d_{2}}=-0.75 \times 4.14=-3.11
\end{aligned}
$$

$\beta m, C_{h} \cdot m$ の概算值はまず式 (35) を用いて各節点の $\dot{M}_{A}$ を求めたうえで, 図上にて式 $(31 \mathrm{~b})$ より算出すれ ばよく, 本例では節点 $d 2, c 2, \cdots, d 3, \cdots, a 3$ の順に, 図一13 (b) 上において計算を進めた。すなわち, 式 （35）を用いて節点 $c 2$ の $\dot{\boldsymbol{M}}_{c 2}$ を求めれば, $S_{c 2}=0$, $\Sigma\left[M_{R}\right]_{A B}=-10.22, \Sigma[\beta m]_{B A}=2.56$ より $\stackrel{\boldsymbol{M}}{c 2}=$ - 7.66 をうる。つぎに,この值を用いて式 (31 b) より $[\beta m],\left[C_{h} \cdot m\right]$ を被乗数一定の積算にて算出すれば,

$[\beta m]_{c 2, b_{2}}=[\beta m]_{c 2, d_{2}}=1.28,[\beta m]_{c 2, c 3}=0.64$

$\left[C_{h} \cdot m\right]_{c 2, c 1}=\left[C_{h} \cdot m\right]_{c 2, c 3}=0.32$

これらの值をそれぞれ所定の $\beta \mu$-欄 および $C_{h} \cdot \mu$-欄 に記入したのち，つぎの節点 $b 2$ に移る。節点 $b 2$ では $S_{b_{2}}=0, \Sigma\left[M_{R}\right]_{A B}=-10.22, \Sigma[\beta m]_{B A}=1.28$ である

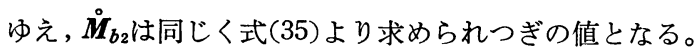

$$
{\stackrel{\circ}{\boldsymbol{M}_{2}}}=0-10.22+1.28=-8.94
$$

よって，この值を用いて図上で $[\beta m],\left[C_{h} \cdot m\right]$ を前 節点の場合と同様に式 $(31 \mathrm{~b})$ より算出する。以下演算 操作はまったく同様である。ただし図一13(b) 中でカッ コのついている各值は, それぞれ各節点で算出された上 記 $\beta m$ および $C_{h} \cdot m$ の概算值である。

(ii） バランス計算および端モーメントの算出：上記 準備計算で求めた概算值をまず式 (13) に代入して $M_{R}$ の第 1 次近似值を求め, ついで回転成分 $m$ の第 1 次近 似值を式 (6), (9) より算出する。

以下式 (13) および式 (6)，(9) に基づく通常のバラン ス計算に移行する (図一13 (b) 参照)。所要の精度に各 值がおさまれば式 (1) より $M_{L}=0$ として各端モーメン トを算定する。すなわち，節点 $d 2$ においては，

$$
\begin{aligned}
& M_{d_{2}, d_{1}}=2.50-7.36+2.67=-2.19 \\
& M_{d_{2}, d_{3}}=2.50-0.16-3.61-2.67=-3.94 \\
& M_{d_{2}, c_{2}}=5.00+1.15=6.15 \quad \text { (単位 }: \mathrm{t} \cdot \mathrm{m} \text { ) }
\end{aligned}
$$

\begin{tabular}{|c|c|c|c|c|c|c|c|}
\hline \multirow{2}{*}{$M_{R}$} & \multicolumn{2}{|c|}{ 概 算 值 } & \multicolumn{2}{|c|}{ 第 1 次近似值 } & \multicolumn{2}{|c|}{ 第 2 次近似値 } & \multirow{2}{*}{ 収束値 } \\
\hline & $\begin{array}{r}\text { 本 法 } \\
(\times 6)\end{array}$ & 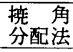 & $\begin{array}{l}\text { 本 法 } \\
(\times 6)\end{array}$ & 㳯配角 & $\begin{array}{l}\text { 本 法 } \\
(\times 6)\end{array}$ & $\begin{array}{l}\text { 摬 角 } \\
\text { 分配法 }\end{array}$ & \\
\hline & -18.66 & -24.8 & -21.72 & -28.0 & -21.66 & -23.0 & -21.60 \\
\hline$a 3, a 2$ & -42.66 & -54.0 & -44.46 & -48.0 & -44.16 & -44.8 & -44.14 \\
\hline
\end{tabular}

本法と暁角分配法との比較のため, まず概算值ならび にこれに基づく第 1 ，第 2 次近似值を列挙すれば 表-4 のごとくである。すなわち， $M_{R}$ の概算值ならびに第 1 , 第 2 次近似值のいずれにおいても本法が 接角分配法

\section{表-4}

より収束值（暁角分配法）にはるかに近く，ために本例 ではバランス計算回数が挩角分配法の 4 回に対して 2 回 で済むことになる。その理由は暁角分配法における暁角, 捹度の概算值推定法が本法に比して単純粗雑であり, 推 定度が低いことが主因かと思われる。

図-14
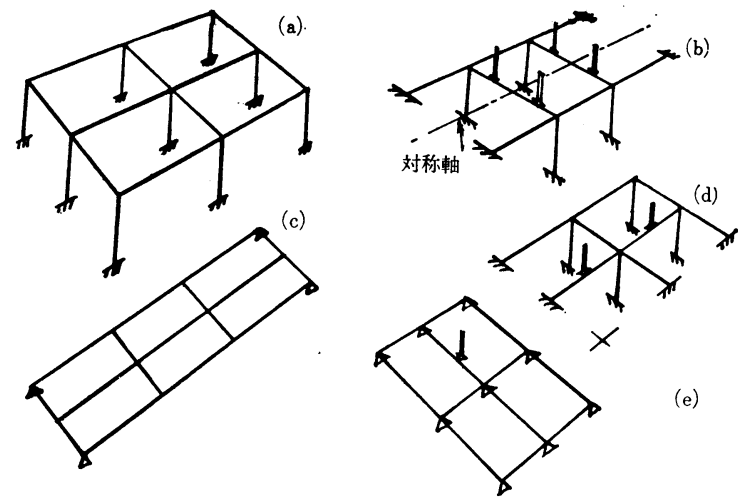

図-13(b) と図一13 図-15

(c) との比較によって 考察するとき, 両者間 には，一見差異は認め られぬかのようである が, 内容に立ち至れば 本法では演算が加減と 積算に完全に分離され ており，しかも積算は 被乗数が一定になって

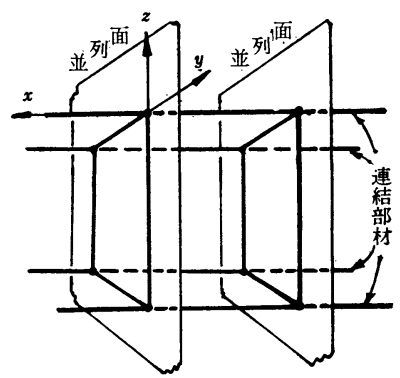
いるので演算面における単純性と一貫性が認められて実 際演算を行なってはるかに便利であることを実感するの みならず，さらに端モーメントが算出值をそのまま加算 して求められるのに対し，暁角分配法ではたわみ角式に もどしてモーメント量への換算計算が必要であり, その 手間が余分である。

\section{3. 直線部材で構成される立体ラーメンの解法}

\section{（1）定義および規約}

本章で取扱う構造物は 図一14 のごとく互いに直交す る直線部材で構成される立体ラーメンや格子桁などであ り一般にこれらの構造物は 図一15 のごとく同一平面の 部材群によって形成される並列面と, この平面に直交す る部材群, 換言すればこれらの並列面を相互に連結する 部材群とによって構成されると見做すことができ，並列 面の部材を面部材, 後者のそれを連結部材と名付ける。 
いま立体構造物を規制するため直交座標 $(x, y, z)$ を導 入すれば，一般に前記立体構造物はつぎの 3 種の形式に 分類される。すなわち，

形式 $(\boldsymbol{x}): y z$ 面部材と $x$ 方向の連結部材との組合せ。 形式 $(y): z x$ 面部材と $y$ 方向の連結部材との組合せ。 形式 $(z): x y$ 面部材と $z$ 方向の連結部材との組合せ。

さて, 力およびモーメントなどの諸力と, 変位および 回転角などの諸変形は, いずれも $x, y, z$ 方向の 3 成分 に分解されるゆえ, たとえば形式 $(x)$ について考察すれ ば，面部材には $x$ 軸に関する曲げモーメント $M^{x}$ と $y$, $z$ 軸方向の力 $F^{y}, F^{z}$ とが作用し, さらにこれに対応し て $x$ 軸回りの回転角すなわち $y z$ 面部材のたわみ角 $\theta^{x}$ と $y, z$ 軸方向の変位 $\Delta^{y}, \Delta^{z}$ とがそれぞれ与えられ, 連 結部材には $x$ 軸に関するねじりモーメント $M^{x}$ が働き， したがって $x$ 軸回りにねじり角 $\theta^{x}$ が生ずる。形式 $(y)$, （z）についても同様な考察が行なわれ，これらの関係を 整理すれば表一5 のごとくである。ただし，モーメント および回転角（たわみ角，ねじり角）の符号は負軸に向 かって右回りをいずれも正とする。

表一5

\begin{tabular}{|c|c|c|}
\hline & 面 & 連 結 部 材 \\
\hline $\begin{array}{l}\text { 形式 } \\
(x)\end{array}$ & $\begin{array}{l}\text { 曲げモーメント } M^{x}, \text { たわみ角 } \theta^{x} \\
\text { 力 } F^{y}, F^{z} \text {, 変位 } \Delta^{y}, \Delta^{z}\end{array}$ & $\begin{array}{l}\text { ねじりモーメント } M^{x} \\
\text { ねじり角 } \theta^{x}\end{array}$ \\
\hline $\begin{array}{l}\text { 形式 } \\
(y)\end{array}$ & $\begin{array}{l}\text { 曲げモーメント } M^{y}, \text { たわみ角 } \theta^{y} \\
\text { 力 } F^{z}, F^{x} \text {, 変位 } \Delta^{z}, \Delta^{x}\end{array}$ & $\begin{array}{l}\text { ねじりモーメント } M^{y} \\
\text { ねじり角 } \theta^{y}\end{array}$ \\
\hline $\begin{array}{l}\text { 形式 } \\
(z)\end{array}$ & $\begin{array}{l}\text { 曲げモーメント } M^{z}, \text { たわみ角 } \theta^{z} \\
\text { 力 } F^{x}, F^{y} \text {, 変位 } \Delta^{x}, \Delta^{y}\end{array}$ & $\begin{array}{l}\text { ねししりモーメント } M^{z} \\
\text { ねしりり角 } \theta^{z}\end{array}$ \\
\hline
\end{tabular}

部材 $A B$ の材端に働く諸力と変形成分との関係は既 往のたわみ角式およびねじり角式より容易に求められ， 形式 $(i)(i=x, y, z)$ に対して下記のごとくなる。

形式 (i) : (a) 面部材に対して,

$M^{i}{ }_{A B}=\left(\alpha^{i} m^{i}\right)_{A B}+\left(\beta^{i} m^{i}\right)_{B A}+\left(M_{R}^{i}\right)_{A B}+C_{A B}^{i}$

$\left.M_{B A}^{i}=\left(\alpha^{i} m^{i}\right)_{B A}+\left(\beta^{i} m^{i}\right)_{A B}+\left(M_{R}^{i}\right)_{B A}+C_{B A}^{i}\right\}$

ただし，

$\alpha^{i}=4, \beta^{i}=2,\left(M_{R}^{i}\right)_{A B}=\left(M_{R}^{i}\right)_{B A}=-6 E K_{i} R^{i}$ $m^{i}{ }_{A B}=E K_{i} \theta_{A}{ }_{A}, m_{B A}^{i}=E K_{i} \theta_{B}^{i}$

(b) 連結部材に対して,

$$
\left.\begin{array}{rl}
M_{A B}^{i} & =\left(\alpha^{i} m^{i}\right)_{A B}+\left(\beta^{i} m^{i}\right)_{B A}+C^{i}{ }_{A B} \\
M_{B A}^{i} & =\left(\alpha^{i} m^{i}\right)_{B A}+\left(\beta^{i} m^{i}\right)_{A B}+C^{i}{ }_{B A}
\end{array}\right\} .
$$

$K_{i}, G J_{i}: i$ 軸に関する曲げ剛度およびねじり剛性,

$K_{0}$ : 標準曲げ剛度, $h$ : 部材長, $\theta^{i}, R^{i}: i$ 軸回りの回 転角および部材角

\section{（2）節点変位のない直線材立体構造物}

本節では図一14(b) に示すごとく対称荷重をもつ対称 構造物や，図一14(d), (e) のごとき節点変位のない立体
ラーメンを対象として考察を進める。

a) 基本式の誘導 節点変位がない場合には $M_{R}{ }^{i}=$ 0 となるゆえ, 未知数は回転成分 $m^{i}$ のみとなり, 後述 の式（39）を用いて容易に算出することができる。すな わち, 構造物の任意節点 $A$ において節点方程式を立て れば次式をらる。

$$
\sum_{B}^{(\text {面部材) }} M_{A B}^{i}+\sum_{B}^{(\text {(連結部材) }} M^{i}{ }_{A B}-\bar{M}_{A}^{i}=0
$$

ただし, $\bar{M}^{i}{ }_{A}: i$ 軸 $(i=x, y, z)$ に関する節点 $A$ の 外力モーメントを示す。

式 (38) に式 (36)，(37) を代入したうえで整理し, 2.(2) a) の場合と同様に式 (41) で定義される回転係数 $\mu^{i}{ }_{A B}$ を導入すれば，ただちに回転成分の算定式がえら れ次式となる。

$$
\begin{aligned}
& m_{A B}^{i}=T_{A}^{i} \cdot \mu_{A B}^{i},\left(\alpha^{i} m^{i}\right)_{A B}=T_{A}^{i} \cdot\left(\alpha^{i} \mu^{i}\right)_{A B} \\
& \left(\beta^{i} m^{i}\right)_{A B}=T_{A}^{i} \times\left(\beta^{i} \mu^{i}\right)_{A B} \\
& \left(C_{h} \cdot m^{i}\right)_{A B}=T_{A}^{i} \times\left(C_{h} \cdot \mu^{i}\right)_{A B}
\end{aligned}
$$

$$
\begin{aligned}
& \text { ここに, } \\
& \qquad T_{A}^{i}=\boldsymbol{M}_{A}^{i}+\sum_{B}\left(\beta^{i} m^{i}\right)_{B A}, M_{A}^{i}=\sum_{B} C_{A B}^{i}-\bar{M}^{i}{ }_{A}
\end{aligned}
$$

また式 (39) の回転係数 $\mu^{i} A B$ はつぎのごとくなる。

$$
\mu_{A B}^{i}=-\left(k_{i}\right)_{A B} / \sum_{B}\left(\alpha^{i} k_{i}\right)_{A B}
$$

b) 概算值推定法 回転成分 $m^{i}$ の推定法は, 2.(4) a) の場合とまったく同様で, 必要公式のみ示しくわし い説明は省略する。いま, 節点 $A$ の拘束成分を $\boldsymbol{M}^{i}{ }_{A}$ と 寸れば, $\boldsymbol{M}^{i}{ }_{A}$ の推定值 $\stackrel{M}{ }^{i}{ }_{A}$ はつぎの式で求められる。

$$
\left.\begin{array}{l}
{\stackrel{\circ}{\boldsymbol{M}^{i}}}_{A}=t^{i}{ }_{A}\left\{\boldsymbol{M}^{i}{ }_{A}+\sum_{B}\left(\beta^{i} \mu^{i}\right)_{B A} \boldsymbol{M}^{i}{ }_{B}\right\} \\
t^{i}{ }_{A}=1 /\left(1-\boldsymbol{r}_{A}^{i}\right), \quad \boldsymbol{r}_{A}^{i}=\sum_{B}\left(\beta^{i} \mu^{i}\right)_{A B}\left(\beta^{i} \mu^{i}\right)_{B A}
\end{array}\right\}
$$

よって, 節点 $A$ の $\left[\beta^{i} m^{i}\right]_{A B}$ および $\left[C_{h} \cdot m^{i}\right]_{A B}$ は 次式で与えられる。

$$
\left.\begin{array}{l}
{\left[\beta^{i} m^{i}\right]_{A B}={\stackrel{\circ}{M^{i}}}_{A} \cdot\left(\beta^{i} \mu^{i}\right)_{A B}} \\
{\left[C_{h} \cdot m^{i}\right]_{A B}=\stackrel{\circ}{M}_{A}^{i} \cdot\left(C_{h} \cdot \mu^{i}\right)_{A B}}
\end{array}\right\}
$$

特に拘束成分がない節点 $A$ の推定值 $\dot{M}^{i}{ }_{A}$ は, 式 (40)よりすでに算出された他端 $B$ の回転成分の概算值 を $\beta^{i}$ 倍した $\left[\beta^{i} m^{i}\right]_{B A}$ の和で与えられる。

$$
{\stackrel{\circ}{\boldsymbol{M}^{i}}}_{A}=\sum_{\boldsymbol{B}}\left[\beta^{i} m^{i}\right]_{B A}
$$

\section{（3）節点変位のある直線材立体構造物}

節点が変位すれば，これに対応して部材には $M^{i}{ }_{R}$ が 生ずるゆえ, 式 (39) の回転成分の算定には式 (40)の 代りに $M^{i}{ }_{R}$ の影響を考慮したつぎの式 (45) を併用し なければならない。すなわち，

$$
T^{i}{ }_{A}=\boldsymbol{M}^{i}{ }_{A}+\sum_{B}\left(M_{R}^{i}\right)_{A B}+\sum_{B}\left(\beta^{i} m^{i}\right)_{B A}
$$

a) 多主桁 1 層多スパンラーメンに対する特殊解法

ここでは橋梁に多用される 図一16 のごとき多主桁 1 層多スパンラーメンを対象として $M_{R}$ の算定公式の誘 
導を行なう。

図-16

(1) 基本式の誘導 (形式 $(x),(z)$ の組 合せの場合）：任意 の $y z$ 並列面 $a$ を取 り出し, 隣接並列面 をそれぞれ並列面 $o$ および $u$ (図一17参 照）とすれば， $y$ 方 向の水平荷重 $P^{y}$ に よってこれらの並列

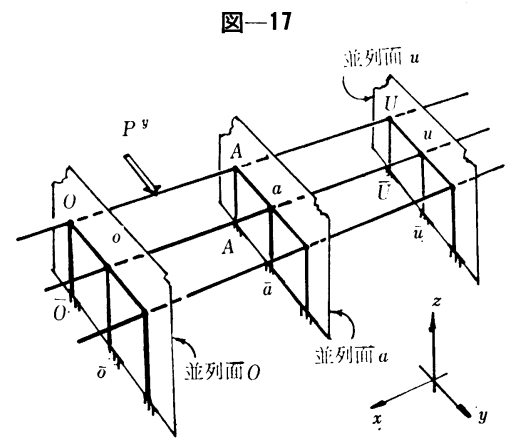

面の柱 $A \bar{A}$ (および $a \bar{a})$ ， $O \bar{O}(お よ ひ ゙ ~ o \bar{o})$ および 柱 $U \bar{U}$ (および $u \bar{u})$ に は $x$ 軸回りの部材角 $R^{x}$ が,はり $A O($ および $a o)$ およびはり $A U$ (および au）には，いずれも $z$ 軸 回りの部材角 $R^{z}$ が生ず る。

注 : 大文字 $A, O$ およ び $U$ は各並列面の 最左端の上側節点記

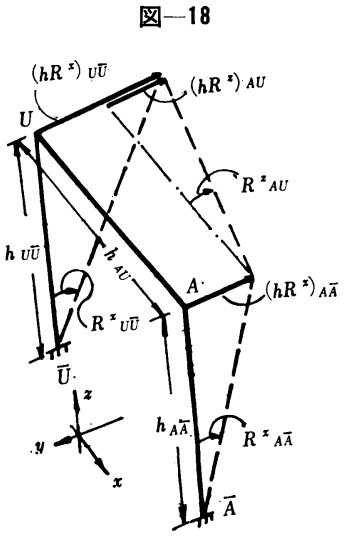
号を表わし，小文字

$a, o$ および $u$ は, 各並列面に含まれるその他の上 側任意節点に対する総称である。

一般にはり $A U$ と柱 $A \bar{A}$ および柱 $U \bar{U}$ の部材角の 間には図一18よりつぎの関係式が成立する。

$\left(h R^{z}\right)_{A U}+\left(h R^{x}\right)_{A \bar{A}}=\left(h R^{x}\right)_{U \bar{U}}$

式 (36) より $R^{i}=-\left(M^{i}{ }_{R}\right) / 6 E K_{0} k_{i},(i=x, z)$ とな り，上式に代入すれば，

$$
\begin{aligned}
& \left(M_{R}{ }^{z}\right)_{A U}=\left(C_{h} \cdot k_{z}\right)_{A U} \\
& \quad \times\left\{\left(M^{x}{ }_{R} / C h \cdot k_{x}\right)_{U \bar{U}}-\left(M^{x}{ }_{R} / C_{h} \cdot k_{x}\right)_{A \bar{A}}\right\}
\end{aligned}
$$

一方, $\left(M_{R}^{z}\right)_{a u}$ と $\left(M_{R}^{z}\right)_{A U}$ とは,

$\left(M^{z}\right)_{a u}=\left(M_{R}^{z}\right)_{A U} \cdot\left(C_{h} \cdot k_{z}\right)_{a u} /\left(C_{h} \cdot k_{z}\right)_{A U}$ なる関係があり，これを用いて上式より $\left(M^{z}{ }_{R}\right) A U$ を消 去すれば, 結局はり $a u$ の部材角成分 $\left(M^{z}{ }_{R}\right) a u$ が柱 $A \bar{A}$ および柱 $U \bar{U}$ の両部材角成分によってつぎのごと
く一般表示される。

$\left(M_{R}^{z}\right)_{a u}=\nu_{a u}^{z}\left[\psi U \bar{U}\left(M_{R}^{x}\right)_{U \bar{U}}-\psi_{A \bar{A}}\left(M_{R}^{x}\right)_{A \bar{A}}\right]$

(46 a)

ここに, $\nu_{a u}^{z}=\left(C_{h} \cdot k_{z}\right)_{a u}, \psi_{U \bar{U}}=1 /\left(C_{h} \cdot k_{x}\right) U \bar{U}$,

$$
\psi_{A \bar{A}}=1 /\left(C_{h} \cdot k_{x}\right) A \bar{A}
$$

同じく $\left(M^{z}{ }_{R}\right)_{a o}$ も柱 $A \bar{A}$ および柱 $O \bar{O}$ の部材角 成分によって表わされ次式となる。

$\left(M_{R}^{z}\right)_{a o}=\nu_{a o}^{z}\left[\psi_{A} \bar{A}\left(M_{R}^{x}\right)_{A \bar{A}}-\psi_{O \bar{O}}\left(M_{R}^{x}\right)_{o \bar{O}}\right]$

ここに, $\nu_{a o}^{z}=\left(C_{h} \cdot k_{z}\right)_{a o}, \psi_{o} \bar{o}=1 /\left(C_{h} \cdot k_{x}\right)_{o \bar{o}}$

図-19

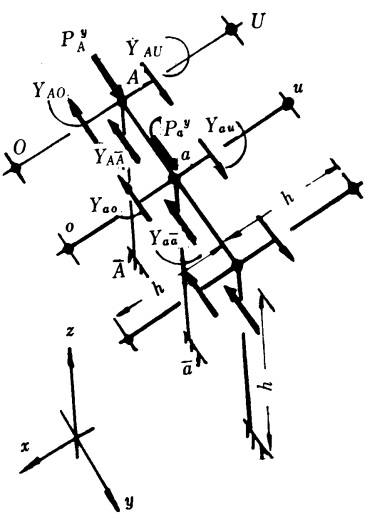

さて, 柱 $A \bar{A}$ および柱 $a \bar{a}$ の部材角成分 $\left(M^{x}{ }_{R}\right) A \bar{A}$ および $\left(M^{x}{ }_{R}\right)_{a \bar{a}}$ の算定式は, $y$ 軸方向の力の釣合式よ り下記のごとく誘導される。すなわち, 節点 $A$ と節点 $a$ を通る $y$ 軸方向の力の釣合式より（図一19 参照）。

$$
\begin{array}{r}
\sum_{a} \boldsymbol{P}_{a}^{y}-\sum_{a} Y_{a \bar{a}}-\sum_{a} Y_{a o}+\sum_{a} Y_{a u}=0 \\
\left(\underset{a}{\sum} \text { には節点 } A\right. \text { も含む) }
\end{array}
$$

ここに，Y $Y_{a \bar{a}}, Y_{a o}$ および $Y_{a u}$ はそれぞれ柱 $a \bar{a}$ ，は り $a o$ およびはり $a u$ の材端 $a$ に働く $y$ 軸方向の端せん 力で次式で与えられる。

$$
\left.\begin{array}{l}
Y_{a \bar{a}}=\frac{-1}{h}\left(M_{a \bar{a}}^{x}+M^{x_{a} a}\right)+Y_{a \bar{a}} \\
Y_{a o}=\frac{-1}{h}\left(M_{a o}^{z}+M_{o a}^{z}\right)+Y_{a o} \\
Y_{a u}=\frac{-1}{h}\left(M_{a u}^{z}+M^{z}{ }_{u a}\right)+Y_{a u}
\end{array}\right\}
$$

ただし, $\boldsymbol{Y}$ : 荷重による $y$ 方向の端せん力, $\boldsymbol{P}^{y}{ }_{a}$ : 節 点 $a$ に働く $y$ 方向の外力を表わす。

式 (48) に標準部材長 $h_{0}$ を乗じたのち, 式 (49), (36) および式 (46a), (47) を代入して整理し， かつ $\left(M^{x}{ }_{R}\right)$ $a \bar{a}=\left(M_{R}^{x}\right)_{A \bar{A}} \cdot\left(C_{h} \cdot k_{x}\right)_{a \bar{a}} /\left(C_{h} \cdot k_{x}\right)_{A \bar{A}}$ なる関係式を導 入すれば, 結局 $\left(M^{x}\right)_{a \bar{a}}$ がつぎの式で求められる。

$$
\begin{gathered}
\left(M_{R}^{x}\right)_{a \bar{a}}=\nu^{x} a \bar{a}\left[\boldsymbol{Q}^{x}{ }_{a}-A_{1}\left(M^{x}{ }_{R}\right)_{o \bar{O}}-A_{2}\left(M^{x}{ }_{R}\right)_{U \bar{U}}\right. \\
\quad+\sum_{a}\left(\mathrm{C}_{h} \cdot m^{x}\right)_{a \bar{a}}+\sum_{a}\left\{\left(C_{h} \cdot m^{z}\right)_{a o}+\left(C_{h} \cdot m^{z}\right)_{o a}\right\} \\
\left.\quad-\sum_{a}\left\{\left(C_{h} \cdot m^{z}\right)_{a u}+\left(C_{h} \cdot m^{z}\right)_{u a}\right\}\right] \cdots \cdots \cdots \cdot(50 \mathrm{a})
\end{gathered}
$$

ただし， 


$$
\begin{aligned}
\boldsymbol{Q}^{x}{ }_{a}= & \frac{1}{6}\left\{Q^{y}{ }_{a} \cdot h_{0}+\sum_{a} C_{h} \cdot\left(C^{x} a \bar{a}+C^{x} \bar{a} a\right)\right. \\
& \left.+\sum_{a} C_{h} \cdot\left(C^{z}{ }_{a o}+C^{z}{ }_{o a}\right)-\sum_{a} C_{h} \cdot\left(C^{z}{ }_{a u}+C^{z}{ }_{u a}\right)\right\}: \\
& \text { 並列面 } a \text { の拘束成分と名付ける。 } \\
Q^{y}{ }_{a} & =\sum_{a} \boldsymbol{P}^{y}{ }_{a}-\sum_{a} \boldsymbol{Y}_{a \bar{a}}-\sum_{a} \boldsymbol{Y}_{a o}+\sum_{a} \boldsymbol{Y}_{a u} \\
A_{1} & =\sum_{a}\left(C_{h}{ }^{2} \cdot k_{z}\right)_{a o} / 3\left(C_{h} \cdot k_{x}\right)_{o \bar{o}} \\
A_{2} & =\sum_{a}\left(C_{h}{ }^{2} \cdot k_{z}\right)_{a u} / 3\left(C_{h} \cdot k_{x}\right)_{U \bar{U}}
\end{aligned}
$$

また, $\nu^{x}{ }_{a \bar{a}}$ は柱 $a \bar{a}$ の部材角係数で次式で示される。

$$
\begin{aligned}
\nu_{a a}^{x}= & -3\left(C_{h} \cdot k_{x}\right)_{a \bar{a}} /\left\{\sum_{a}\left(C_{h}{ }^{2} \cdot k_{x}\right)_{a \bar{a}}\right. \\
& \left.+\sum_{a}\left(C_{h}{ }^{2} \cdot k_{z}\right)_{a o}+\sum_{a}\left(C_{h}{ }^{2} \cdot k_{z}\right)_{a u}\right\}
\end{aligned}
$$

(2) 概算值推定法 : 並列面 $a$ の任意の柱 $a \bar{a}$ 亿生ずる $x$ 軸回りの部材角成分 $\left(M^{x}{ }_{R}\right)_{a \bar{a}}$ の概算值は, 2.(4) b) と同様な方法によって簡単に推定することができる。す なわち, 図一17 のごとき立体ラーメンの並列面 $a$ の拘 束成分を $\boldsymbol{Q}^{\boldsymbol{x}}{ }_{\boldsymbol{a}}$ とすれば, 推定值 $\stackrel{Q}{\boldsymbol{Q}}^{x}{ }_{\boldsymbol{a}}$ は式 (33) より 次式でえられる。

$$
{\stackrel{\circ}{\mathbf{Q}^{x}}}_{a}=t^{x}{ }_{a} \cdot \boldsymbol{Q}^{x}{ }_{a}, t^{x}{ }_{a}=1 /\left(1-\boldsymbol{r}_{a}^{x}\right)
$$

また, 部材角成分の概算值は式 (34) より,

$$
\left[M^{x}\right]_{a \bar{a}}=\nu_{a \bar{a}}^{x} \cdot \stackrel{\circ}{Q}^{x}{ }_{a}
$$

さらに任意節点 $A$ の拘束成分 $\boldsymbol{M}^{i}{ }_{A}$ の推定值 $\stackrel{\circ}{\boldsymbol{M}}^{i}{ }_{A}$ は, 式 (42) の代りに $\left[M^{i}{ }_{R}\right]$ の影響を加味した次式で 算出される。

$$
\left.\begin{array}{rl}
\stackrel{\circ}{M}^{i} & =S^{i}{ }_{A}+\sum_{B}\left[M^{i}{ }_{R}\right]_{A B}+\sum_{B}\left[\beta^{i} m^{i}\right]_{B A} \\
S^{i}{ }_{A} & =t^{i}{ }_{A} \cdot M^{i}{ }_{A}
\end{array}\right\} \cdots
$$

ここに, 式 (52) の項比 $\boldsymbol{r}^{x}{ }_{a}$ はつぎのごとき内容と なる。

$$
\boldsymbol{r}_{a}^{x}=p_{a \bar{a}}+\nu^{x} A \bar{A}\left(A_{1} f_{1}+A_{2} f_{2}+q_{1}+q_{2}\right)
$$

ただし，

$$
\begin{aligned}
p_{a \bar{a}} & =\sum_{a}\left(C_{h} \cdot \mu^{x} \cdot \nu^{x}\right)_{a \bar{a}} \\
f_{1} & =\nu^{x} o \bar{o} \sum_{a}\left(C_{h}{ }^{2} \cdot k_{z}\right)_{o a} / 3\left(C_{h} \cdot k_{x}\right)_{A \bar{A}} \\
f_{2} & =\nu^{x} U \bar{U} \sum_{a}\left(C_{h} \cdot k_{z}\right)_{u a} / 3\left(C_{h} \cdot k_{x}\right)_{A \bar{A}} \\
q_{1} & =\psi_{A A} \sum_{a}\left\{\left(C_{h} \cdot \mu^{z}\right)_{a o}+\left(C_{h} \cdot \mu^{z}\right)_{o a} \nu^{z} \nu_{a o}\right. \\
q_{2} & =\psi_{A \bar{A}} \sum_{a}\left\{\left(C_{h} \cdot \mu^{z}\right)_{a u}+\left(C_{h} \cdot \mu^{z}\right)_{u a} \nu^{z}{ }_{a u}\right.
\end{aligned}
$$

特に節点 $a$ と $u$ の変形が対称な場合には対称条件より えられる $f_{2}=-1, q_{2}=0$ の諸值を式 (55) に代入して，

$$
\boldsymbol{r}_{a}^{x}=p_{a \bar{a}}+\nu^{x} a \bar{a}\left(A_{1} f_{1}-A_{2}+q_{1}\right)
$$

また節点 $A$ と節点 $a$ を結ぶ軸がこれら節点 $u$ と $o$ の 変形に関する対称軸に該当する場合は, $A_{2} f_{2}=A_{1} f_{1}$, $q_{2}=q_{1}=\psi_{A \bar{A}} \sum_{a}\left(C_{h} \cdot \mu^{z} \cdot \nu^{z}\right)_{o a}$ とおいてつぎの值となる。

$$
\boldsymbol{r}_{a}^{x}=p_{a \bar{a}}+2 \nu_{a \bar{a}}^{x}\left(A_{1} f_{1}+q_{1}\right)
$$

注 : 形式 $(y),(z)$ の組み合せに対する基本式は単に

上記誘導諸式の肩字 $x$ を $y$ に代えたものとなる。

(3) 柱の $M_{R}$ 補正法: 柱 $a \bar{a}$ の $M_{R}$ の収㪘が $m$ の それにくらべて悪い場合は, 式 (55) （57）で与えられ る項比をそのまま使用することによって， $M_{R}$ を2.(3) b）とまったく同じ方法で容易に補正することができる。 b) 一般解沠 図一20(a) の多層多スパン立体ラー

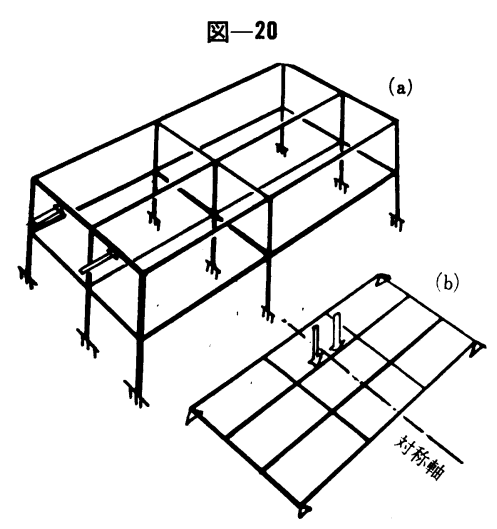

メンや図一20(b) の多主桁多スパン格子析を前述の方法 で解こうとすれば $M_{R}$ 算定式が繁隻となり実用性が損 われる。したがってかかる構造物の解法には 2. (3) d) (1) のごとく重ね合せの方法を本法に適用するのが有利 である。この場合すべて変位は定数として扱うゆえ, 式 (45) の $M^{i}{ }_{A}+\sum_{B}\left(M^{i}{ }_{R}\right)_{A B}$ も同じく定数となる。よっ て回転成分 $m^{i}$ の算定法が節点変位のない場合と同一と なり, 式 (39) をそのまま算定式とみなしえて演算操作 が簡単となる。また 3.(2) b) の概算值推定法を適用す れば，上記分割計算はいずれも 2 回あるいは 3 回のバラ ンス計算で収束するゆえ，演算量が軽減される反面，節 点変位数と同じ元数をもつ補正係数に関する連立方程式 を解かねばならないので, 究極のところ回転変形は多く とも，節点変位の少ない一般構造物に対して本法が実用 的価值を有するといえ, 節点変位数を 12 以下に限定し ても 図一20(a) は一般に水平変位 12 , 構造および荷重 が対称のときは 4 , 図一20 (b) は垂直変位 12 , 同じく 対称で 6 となり, この程度のかなり複雑な構造物でも割 合楽に解けることがわかる。

c) 計算例一 3 図一21 に示す 2 主桁 1 層 3 スパン のラーメンを例として 3.(3) a) による演算を解説する。

（i）準備計算: 構造形式と荷重の対称性より, 節点 $c i, d i(i=1,2)$ 側の半分を計算すればよく, さらに載荷 条件より形式 $(x)$ および形式（z) を採用する。さて,

\section{图-21}

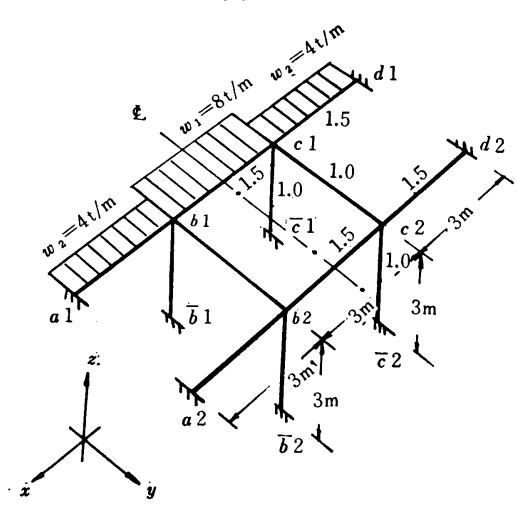


図-22

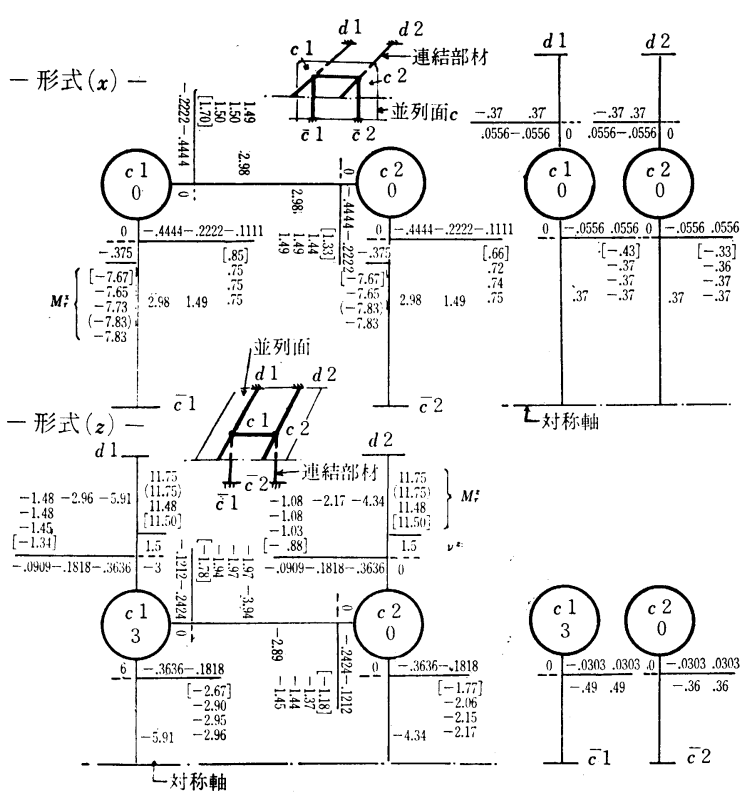

節点の回転係数 $\mu$ および $\alpha \mu, \beta \mu, C_{h} \cdot \mu$ はそれぞれ 図 一22 のごとくえられる。また部材長はすべて等しく $C_{h}=h_{i j} / h_{i}=1$ より, 式 (50a) の諸係数は,

$$
\begin{aligned}
& A_{1}=\left(1^{2} \times 1.5+1^{2} \times 1.5\right) / 3 \times(1 \times 1)=1 \\
& \psi_{c_{1}, \overline{c_{1}}=}=1 /(1 \times 1)=1, \nu^{z}{ }_{c 1}, d_{1}=\nu^{z}{ }_{c 2}, d_{2}=1 \times 1.5=1.5 \\
& \nu_{c_{1}, \overline{c_{1}}}^{x}=\nu^{x}{ }_{c 2}, \overline{c_{2}}=-3(1 \times 1) /\left\{2 \times\left(1^{2} \times 1\right)\right. \\
& \left.\quad+2 \times\left(1^{2} \times 1.5\right)+2 \times\left(1^{2} \times 1.5\right)\right\}=-0.375
\end{aligned}
$$

さらに並列面 $c$ の拘束成分 $\boldsymbol{Q}^{x}{ }_{c}$ は $Q^{y}{ }_{c}=8 \times 3 / 2+4 \times$ $3 / 2=18.0$ を式（50a）に代入すればただちに算定でき， $\boldsymbol{Q}^{x}{ }_{c}=\{18.0 \times 3+1 \times 0\} / 6=9.0$ となる。

したがって式 (50a)，(46a) は本例の場合つぎのごと く表わされる。

$$
\begin{aligned}
\left(M_{R}^{x}\right)_{c i, \overline{c i}}= & \nu_{c i, \overline{c i}}^{x}\left[9.0-\left(M_{R}^{x}\right)_{b_{1}, \overline{b 1}}\right. \\
& \left.+\sum_{i}\left(C_{h} \cdot m^{x}\right)_{c i, \overline{c i}}-\sum_{i}\left(C_{h} \cdot m^{z}\right)_{c i, d i}\right]
\end{aligned}
$$

$\left(M^{z}\right)_{c i, d i}=\nu^{z}{ }_{c i, d i}\left[-\left(M^{x}\right)_{c 1}, \overline{c_{1}}\right] \cdots \cdots(46 \mathrm{~b})$

一方, 項比 $\boldsymbol{r}^{x}{ }_{c}$ は, 式 (55) より節点 $b i$ と $c i$ の変 形が対称で 節点 $d i$ が固定ゆえ $f_{1}=-1, q_{1}=0$ および $f_{2}=0$ とおいて,

$$
\begin{aligned}
& \boldsymbol{r}_{c}^{x}=p_{c \bar{c}}+\nu^{x}{ }_{c_{1}, \overline{c 1}}\left(-A_{1}+q_{2}\right) \\
& \text { ここで, } \\
& p_{c \vec{c}}=2(-0.1111) \times(-0.375) \fallingdotseq 0.083 \\
& q_{2}=1 \times 2 \times(-0.0909) \times 1.5 \fallingdotseq-0.2727 \\
& \nu_{c_{1}, \overline{c 1}}^{x}=-0.375, A_{1}=1 \\
& \text { よって, } \\
& \boldsymbol{r}^{x}=0.083+(-0.375)(-1-0.2727) \fallingdotseq 0.56 \\
& t^{x}{ }_{c} \fallingdotseq 2.27
\end{aligned}
$$

すなわち, 並列面 $c$ の拘束成分 $\boldsymbol{Q}^{x}{ }_{c}$ の推定值 $\stackrel{\boldsymbol{Q}}{ }^{x}{ }_{c}$ は 式 (52)より,

$$
{\stackrel{\circ}{\boldsymbol{Q}^{x}}}_{c}=t^{\boldsymbol{x}}{ }_{c} \cdot \boldsymbol{Q}^{\boldsymbol{x}}{ }_{c}=2.27 \times 9.0 \fallingdotseq 20.4
$$

また節点 $c 1$ の拘束成分は $\boldsymbol{M}_{c_{1}}=C^{z}{ }_{c_{1}, b_{1}}+C^{z}{ }_{c_{1}, d_{1}}$ $=8 \times 3^{2} / 12-4 \times 3^{2} / 12=3.0$ となり, 項比 $\boldsymbol{r}^{z}{ }_{c_{1}}=$ $(-0.1818)^{2}+(-0.1212)^{2} \fallingdotseq 0.05, t^{z}{ }_{c 1}=1.05$ を式 (54)に代入すれば,同節点の $S^{z}{ }_{c 1}$ として次值をうる。

$$
S^{z}{ }_{c 1}=t^{z}{ }_{c 1} \cdot M_{c_{1}}=1.05 \times 3.0 \fallingdotseq 3.2
$$

(ii) バランス計算 : $x$ 軸に関する回転成分 $m^{x}$ と 部材角成分 $M^{x}{ }_{R}$ に対して $y z$ 面部材と $x$ 方向の連結 部材を, $z$ 軸に関する $m^{z}$ と $M^{z}{ }_{R}$ に対して $x y$ 面部 材と $z$ 方向の連結部材をそれぞれ 図一22 のごとく並 記する。つぎに $\mu^{j}$ および $\alpha^{j} \mu^{j}, \beta^{j} \mu^{j}, C_{h} \cdot \mu^{j}(j=x, z)$ などを平面ラーメンの記入法に準じて書き入れたのち まず部材角成分の概算値を算出する。

柱 $c_{i}, \bar{c}_{i}(i=1,2)$ では式 (53) より,

$$
\left[M_{R}^{x}\right]_{c i, \overline{c i}}=-0.375 \dot{Q}^{x}{ }_{c} \fallingdotseq-7.67
$$

よって対称条件より, $\left[M^{x}\right]_{b i, \overline{b i}}=-7.67$

さらにはり $c i, d i$ では式 $(46 \mathrm{~b})$ より，

$\left[M_{R}^{z}\right]_{c i, d i} \fallingdotseq 11.50$

また $[m]$ を各節点ごとに式 (54)，(53) より順次 算定すればそれぞれ以下のごとくなる。すなわち, 形式 (x) について示せば,

節点 $c 1$ では :

$$
\begin{aligned}
& S^{x}{ }_{c 1}=0, \sum_{B}\left[M^{x}\right]_{A B}=-7.67 \\
& \sum_{B}\left[\beta^{x} m^{x}\right]_{B A}=0 \text { より }{\stackrel{\circ}{\boldsymbol{M}^{x}}}_{c 1}=-7.67 \\
& \text { よって式 (43) より, } \\
& \begin{array}{l}
{\left[\beta^{x} m^{x}\right]_{c_{1}, c_{2}}=-7.67 \times(-0.2222) \fallingdotseq 1.70} \\
{\left[\beta^{x} m^{x}\right]_{c_{1}, b_{1}}=-7.67 \times(0.0556) \fallingdotseq-0.43} \\
{\left[C_{h} \cdot m^{x}\right]_{c_{1}, \overline{c_{1}}}=-7.67 \times(-0.1111) \fallingdotseq 0.85}
\end{array}
\end{aligned}
$$

節点 $c 2$ では :

$$
\begin{aligned}
& S_{c 2}^{x}=0, \sum_{B}\left[M_{R}^{x}\right]_{A B}=-7.67 \\
& \sum_{B}\left[\beta^{x} m^{x}\right]_{B A}=1.70 \text { より }{\stackrel{\circ}{M^{x}}}_{c 2}=-5.97 \\
\text { よって式 (43) より, } & {\left[\beta^{x} m^{x}\right]_{c 2, c 1}=-5.97 \times(-0.2222) \fallingdotseq 1.33 } \\
& {\left[\beta^{x} m^{x}\right]_{c 2, b 2}=-5.97 \times(0.0556) \fallingdotseq-0.33 } \\
& {\left[C_{h} \cdot m^{x}\right]_{c 2, \overline{c 2}}=-5.97 \times(-0.1111) \fallingdotseq 0.66 }
\end{aligned}
$$

形式 $(z)$ についても同様な計算を行なったのち（図一 22 参照), $M^{i}{ }_{R}$ の第 1 次近似值を求める。すなわち,

$$
\begin{aligned}
& {\left[M^{x}\right]_{b_{1}, \overline{b 1}}=-7.67, \sum_{i}\left[C_{h} \cdot m^{x}\right]_{c i, \overline{c i}}=1.51} \\
& \begin{aligned}
\sum_{i}\left[C_{h} \cdot m^{z}\right]_{c i, d i} & =-2.22 \text { より, } \\
\left(M^{x}\right)_{c i, \overline{c i}} & =-0.375(9.0+7.67+1.51+2.22) \\
& =-7.65
\end{aligned} \\
& \left(M^{z}\right)_{c i, d i}=1.5 \times(7.65)=11.48
\end{aligned}
$$

ついで，各節点の回転成分の第 1 次近似值を式 (39), （45）を用いて順次算出したのち，再び $M^{i}{ }_{R}$ の第 2 次近 似值を求めれば式 $(50 \mathrm{~b})$ より,

$$
\begin{aligned}
\left(M_{R}^{x}\right)_{c i, \overline{c i}} & =-0.375(9.0+7.67+1.47+2.48) \\
& =-7.73
\end{aligned}
$$


一般に多主桁の立体ラーメンでは，回転成分に比較し て部材角成分の收㪘が悪く, 本例でも 3.(3) a) (3) の $M_{R}$ 補正法を用いて $M_{R}$ の補正を行なら必要がある。 さて, $M^{x}{ }_{R}$ の変化量 $\Delta M^{x}{ }_{R}$ は第 2 次近似值より第 1 次近似值を差し引いた值 -0.08 となり, 所要の補正值 は式 (16) より $\left(M^{x}\right)_{c i}, \overline{c i}=-7.65+2.27 \times(-0.08)$ $\fallingdotseq-7.83$ よって $\left(M^{z}\right)_{c i, d i}$ は式 $(46 \mathrm{~b})$ よりつぎの 値となる。

$$
\left(M^{z}\right)_{c i, d i}=1.5 \times 7.83=11.75
$$

これらの值よりあらためて回転成分 $m$ の第 2 次近似 值を前回と同じく節点ごとに逐次算出する。かくのごと く式 (39),(45) および式 (50 b)，(46b) を用いて $m$ お よび $M_{R}$ の近似值をくり返し求め, 各值が所要の精度 に達するまで反復を続ける。本例では精度を小数位 2 位 に取れば, $M_{R}$ の補正計算を含め 3 回のバランス計算で 收束することが認められたが (図一22 参照)， $M_{R}$ の補 正を行なわなければ 6 回のバランス計算を必要とし，さ らに概算值推定法によらないで拘束成分をそのまま用い て計算を行なら場合は 12 回にも達する。以上より概算 值推定法と $M_{R}$ 補正法とを併用する本法がかかる $M_{R}$ の収㪘が悪い立体ラーメンに対してもきわめて有効なる 実用解となりらることが了解される。

(iii) 端モーメントの算出: 所要の端モーメントは式 (36) より下記のごとき簡単な加減算によって求められ る。すなわち,

$$
\begin{aligned}
& M^{x}{ }_{c_{1}, c_{2}}=2.98+1.49=4.47 \\
& M^{x}{ }_{c 2, c 1}=2.98+1.49=4.47 \\
& M_{\overline{c_{1}}, c_{1}}^{x_{1}}=-7.83+1.49=-6.34 \\
& M^{x}{ }_{c_{1}, \overline{c_{1}}}=2.98-7.83=-4.85 \\
& M^{x}{ }_{c 2, \overline{c 2}}=-7.83+2.98=-4.85 \\
& M_{d_{1}, c_{1}}^{x_{1}}=-0.37, M_{c_{1}, d_{1}}^{x}=0.37, M^{x}{ }_{c_{2}, d_{2}}=0.37 \\
& M_{\overline{c_{2}}, c_{2}}^{x_{1}}=-7.83+1.49=-6.34 \\
& M^{x}{ }_{c_{1}, b_{1}}=0.37-0.37=0 \\
& M^{x}{ }_{c 2, b 2}=0.37-0.37=0, M^{x}{ }_{d 2, c_{2}}=-0.37 \\
& M^{z}{ }_{c_{1}, d_{1}}=11.75-5.91-3.00=2.84 \\
& M^{z}{ }_{c 2, d_{2}}=11.75-4.34=7.41 \\
& M_{d_{1}, c_{1}}^{z}=11.75-2.96+3.00=11.79 \\
& M^{z}{ }_{c 1, c_{2}}=-3.94-1.45=-5.39 \\
& M^{z}{ }_{c 2, c_{1}}=-2.89-1.97=-4.86 \\
& M^{z}{ }_{d 2, c 2}=11.75-2.17=9.58 \\
& M^{z}{ }_{c 1, b_{1}}=-5.91+2.96+6.00=3.05 \\
& M^{z}{ }_{c 2, b_{2}}=-4.34+2.17=-2.17 \\
& M_{\overline{c_{1}}, c_{1}}^{z_{1}}=0.49, M^{z}{ }_{c_{1}, \overline{c_{1}}}=-0.49
\end{aligned}
$$$$
M^{z}{ }_{c 2, \overline{c_{2}}}=-0.36, M_{\overline{c 2}, c_{2}}^{z}=0.36 \quad \text { (単位 }: \mathrm{t} \cdot \mathrm{m} \text { ) }
$$

\section{4. 曲線部材をもつ立体ラーメンの解法}

\section{（1）定義および規約}

一般に曲線部材をもつ立体ラーメンは, 部材の結合形
式によって下記のごと く大別される。

形式（I）（図-23 (a) 参照)：曲線部材 が材端の接線方向 $(t$ 軸方向）に沿って連続 して結合されている形 式。

形式 (II)：(図-23
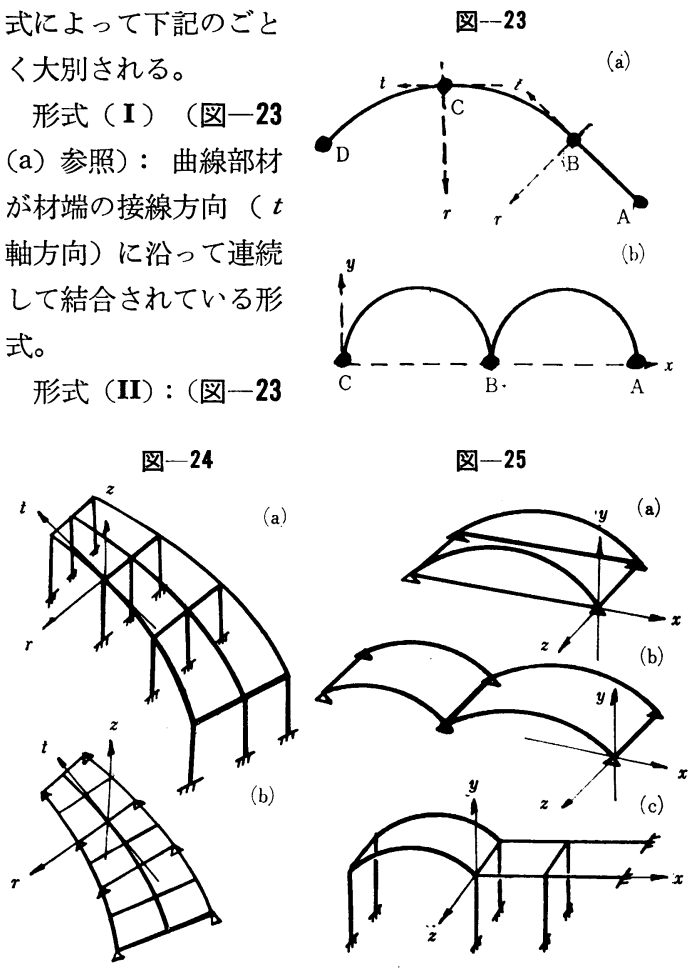

（b）参照）：曲線部材が両材端を通る軸（ $x$ 軸）に沿っ て直線上に結合されている形式。

形式 (I) には高速道路高架橋などに多用される図一24 (a), (b) のごとき多主桁 1 層多スパンの曲線材立体ラー メンや曲線格子桁などがあり, 形式 (II) は図一25 (a) の変型ローゼ桁や (b) の連続アーチおよび (c) の建築 構造ラーメンなどにその例を見る。以下上記 2 形式に分 けて考察を進めることとする。

形式 (I): 座標系として部材の接線, 法線および陪 法線を 3 軸とする流動座標 $(t, r, z)$ を採用する。また 構成部材を 3.(1) の場合と同じく, 並列面内にある面部 材とこれに直交する連結部材とに分ければ, 構造物はつ ぎの 3 形式に分類される (図一24 参照)。

形式 $(r): t z$ 面部材と $r$ 方向の連結部材との組合せ。 形式 $(t): z r$ 面部材と $t$ 方向の連結部材との組合せ。 形式 $(z): r t$ 面部材と $z$ 方向の連結部材との組合せ。

つぎに部材 $A B$ の材端に㗢く端モーメントと変形成 分との関係は, 平面 ${ }^{12)}$ ならびに立体たわみ角式 ${ }^{14)}$ より 容易に求められ，いま曲線として円弧を採用すれば，形 式 $(i)(i=r, t, z)$ に対して式 (2) よりそれぞれ下記の ごとく表わされる(図一26 参照)。

$$
\left.\begin{array}{rl}
M^{i}{ }_{A B}= & \left(\alpha^{i} m^{i}\right)_{A B}+\left(\beta^{i} m^{i}\right)_{B A}+\left(\gamma^{i} m^{j}\right)_{A B} \\
& +\left(\bar{\delta}^{i} m^{j}\right)_{B A}+\left(M^{i}{ }_{R}\right)_{A B}+C^{i}{ }_{A B} \\
M_{B A}^{i}= & \left(\alpha^{i} m^{i}\right)_{B A}+\left(\beta^{i} m^{i}\right)_{A B}+\left(\gamma^{i} m^{j}\right)_{B A} \\
& \left.+\bar{\delta}^{i} m^{j}\right)_{A B}+\left(M^{i}{ }_{R}\right)_{B A}+C^{i}{ }_{B A}
\end{array}\right\}
$$


図-26

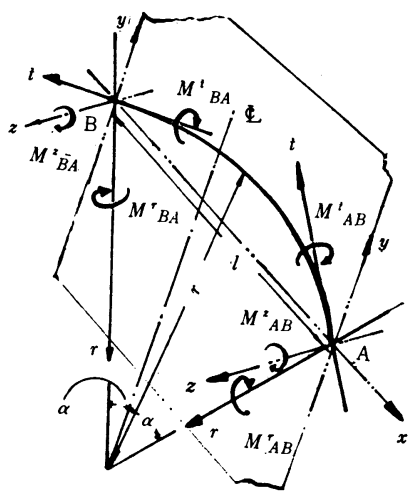

$$
\begin{aligned}
M_{A B}^{z}= & \left(\alpha^{z} m^{z}\right)_{A B}+\left(\beta^{z} m^{z}\right)_{B A} \\
& +\left(M^{z}\right)_{A B}+\left(M^{z}\right)_{A B}+C^{z}{ }_{A B} \\
M_{B A}^{z}= & \left(\alpha^{z} m^{z}\right)_{B A}+\left(\beta^{z} m^{z}\right)_{A B} \\
& +\left(M^{z}\right)_{B A}+\left(M^{z}\right)_{B A}+C_{B A}^{z}
\end{aligned}
$$

ここに肩字 $i, j$ は $i=r, t$ に対して $j=t, r$ をとる。 また回転成分, 部材角成分および伸縮成分はそれぞれ表 一6 のごとき内容をもつ。

ただし, $K_{i}(i=r, t, z): i$ 軸に関する曲げ剛度, $K_{c}=$ $I_{r} / 2 \alpha r$ : 半開角 $\alpha$, 半径 $r$ の円弧部材の $r$ 軸に関する曲 げ剛度, $\boldsymbol{R}=\left(\Delta^{z}{ }_{A}-\Delta^{z}{ }_{B}\right) / r, R^{z}=\left(\Delta^{y}{ }_{B}-\Delta^{y} A\right) / l$ : 円弧部 材の部材角, $l$ : 円弧部材の弦長, $\alpha^{i}, \beta^{i}, r^{i}, \delta^{i}, \varepsilon^{i}(i=r$, $t)$ : 円弧部材の立体たわみ角式の形状項 ${ }^{14)}, \alpha^{z}, \beta^{z}, \gamma^{z}$, $z): i$ 軸に関する固定端モーメント, $\bar{\delta}_{A}=\delta_{B}, \bar{\delta}_{B}=\delta_{A}$

なおモーメントおよび回転角の符号は, $r, t$ 軸回りの ものは正軸に向かって右回りを正とし， $z$ 軸回りのもの $\delta^{z}:$ 円弧部材の平面たわみ角式の形状項 ${ }^{12)}, C^{i}(i=r, t$,

は負軸に向かって右回りを正とする。

形式 (II) : 座標系として直交固定座標 $(x, y, z)$ を採 用すれば, 形式 (I) と同様に構成部材の組み合せはつぎ の 3 形式に分類される (図一25 参照)。

すなわち，

形式 $(x): y z$ 面部材と $x$ 方向の連結部材との組合せ。 形式 $(y): z x$ 面部材と $y$ 方向の連結部材との組合せ。 形式( $z$ ) : $x y$ 面部材と $z$ 方向の連結部材との組合せ。 また, 直交固定座標を規準とする円弧部材の端モ一メ ント式には $i=x, j=y$ または $i=y, j=x$ とおいた式 (58 a) および式 (58 b) がそのまま適用できる。ただし 回転成分, 部材角成分および伸縮成分の式内容は 表-7 に示すごとくである。

\section{（2）形式（I）の立体構造物}

a) 基本式の誘導 構造物の任意節点 $A$ を取り出 し, $i$ 軸 $(i=r, t, z)$ に関する節点方程式を立てれば次 式をえる。

$$
\sum_{B} M_{A B}^{i}-\bar{M}_{A}^{i}=0
$$

ただし, $\bar{M}^{i}{ }_{A}$ : 節点 $A$ に働く $i$ 軸回りの外力モーメ ントである。

式（59）に式（58 a)，(58 b) を代入し，3.(2)a)の 直線材立体構造物の場合と同様に, 式 (62) で定義され る回転係数 $\mu_{A B}^{i}$ を導入したうえで整理すれば, 結局回 転成分の決定式が次式で求められる。

$$
\begin{aligned}
m_{A B}^{i}= & \mu^{i}{ }_{A B}\left[\boldsymbol{M}^{i}{ }_{A}+\sum_{B}\left(\beta^{i} m^{i}\right)_{B A}\right. \\
& \left.+\sum_{B}\left(r^{i} m^{j}\right)_{A B}+\sum_{B}\left(\bar{\delta} m^{j}\right)_{B A}\right]
\end{aligned}
$$

ただし, $\left(\gamma^{z} m^{j}\right)_{A B}=0,\left(\bar{\delta}^{z} m^{j}\right)_{B A}=0$

\begin{tabular}{|c|c|c|c|c|c|c|c|}
\hline & & 線 & 部 材 & \multirow{2}{*}{ 円 } & \multirow{2}{*}{ 弧 } & \multirow{2}{*}{ 部 } & \multirow{2}{*}{ 材 } \\
\hline & 面 & 部 材 & 連 結 部 材 & & & & \\
\hline 回転成分 & \multicolumn{2}{|c|}{$\begin{array}{l}m^{x}=E K_{x} \theta^{x} \\
m^{y}=E K_{y} \theta^{y} \\
m^{z}=E K_{z} \theta^{z}\end{array}$} & $\begin{array}{l}m^{x}=E K_{0} \theta^{x} \\
m^{y}=E K_{0} \theta^{y} \\
m^{z}=E K_{0} \theta^{z}\end{array}$ & & \multicolumn{3}{|c|}{$\begin{array}{l}m^{x}=E K_{c} \theta^{x} \\
m^{y}=E K_{c} \theta^{y} \\
m^{z}=E K_{z} \theta^{z}\end{array}$} \\
\hline 部材角成分 & \multicolumn{3}{|c|}{$\begin{array}{l}\left(M^{x} R\right)_{A B}=\left(M^{x} R\right)_{B A}=-6 E K_{x} R^{x} \\
\left(M^{y}\right)_{A B}=\left(M^{y}\right)_{B A}=-6 E K_{y} R^{y} \\
\left(M^{z} R\right)_{A B}=\left(M^{z} R\right)_{B A}=-6 E K_{z} R^{z}\end{array}$} & \multicolumn{4}{|c|}{$\begin{array}{l}\left(M^{x} R\right)_{A B}=-\left(M^{x} R\right)_{B A}=\varepsilon^{x} A E K_{c} R \\
\left(M^{y} R\right)_{A B}=\left(M^{y}\right)_{B A}=\varepsilon^{y} E K_{c} R \\
\left(M^{z} R\right)_{A B}=\left(M^{z}\right)_{B A}=\gamma^{z}{ }_{A} E K_{z} R^{z}\end{array}$} \\
\hline 伸 縮 成 分 & \multicolumn{3}{|c|}{-} & \multicolumn{4}{|c|}{$\left(M^{z} L\right)_{A B}=-\left(M^{z} L\right)_{B A}=\delta^{z}{ }_{A} E K_{z} \Delta l$} \\
\hline
\end{tabular}

さらに式 (60) より $\alpha^{i}, \beta^{i}, \gamma^{j}, \bar{\delta}^{j}$ を乗じて,

$$
\left.\begin{array}{l}
\left(\alpha^{i} m^{i}\right)_{A B}=T_{A}^{i} \cdot\left(\alpha^{i} \mu^{i}\right)_{A B} \\
\left(\beta^{i} m^{i}\right)_{A B}=T_{A}^{i} \cdot\left(\beta^{i} \mu^{i}\right)_{A B} \\
\left(\gamma^{j} m^{i}\right)_{A B}=T_{A}^{i} \cdot\left(\gamma^{j} \mu^{i}\right)_{A B} \\
\left(\bar{\delta}^{j} m^{i}\right)_{A B}=T_{A}^{i} \cdot\left(\bar{\delta}^{j} \mu^{i}\right)_{A B}
\end{array}\right\}
$$

$$
\text { ここに, }
$$

$$
\begin{aligned}
T^{i}{ }_{A}= & M_{A}{ }^{i}+\sum_{B}\left(\beta^{i} m^{i}\right)_{B A} \\
& +\sum_{B}\left(\gamma^{i} m^{j}\right)_{A B}+\sum_{B}\left(\bar{\delta}^{i} m^{j}\right)_{B A} \\
M_{A}^{i}= & \sum_{B} C^{i}{ }_{A B}-\bar{M}^{i}{ }_{A} \\
& +\sum_{B}\left(M^{i}\right)_{A B}+\sum_{B}\left(M^{i}{ }_{L}\right)_{A B}:
\end{aligned}
$$

表-7
節点 $A$ の $i$ 軸に関する拘束成分 ただし, $\left(\gamma^{j} m^{z}\right)_{A B}=\left(\bar{\delta}^{j} m^{z}\right)_{A B}=0$

$$
\left(M^{r}\right)_{A B}=\left(M^{t}\right)_{A B}=0
$$

とする。

また, 式 (60), (61) の回転係数は次式と なる。

$$
\begin{aligned}
\mu_{A B}^{i} & =-m_{A B}^{i} / \sum_{B}\left(\alpha^{i} m^{i}\right)_{A B} \\
& =-\left.\left(k_{i}\right)_{A B}\right|_{B}\left(\alpha^{i} k_{i}\right)_{A B}
\end{aligned}
$$


ただし, $k_{i}=K_{i} / K_{0}$ は $i$ 軸に関する剛比で, 特に円弧 部材に対しては $k_{r}=k_{t}=K_{c} / K_{0}$ となる。

なお式 (62) の回転係数の検算には次式が用いられる。

$$
\sum_{B}\left(\alpha^{i} \mu^{i}\right)_{A B}=-1
$$

b) 概算值推定法 回転成分 $m$ の概算值推定法は 3.(2) b) で述べた方法をそのまま踏襲する。すなわち, 円弧部材を対象とする場合, 式 (42) の項比 $\boldsymbol{r}^{i}{ }_{A}$ は式 (61) よりつぎの内容にかわる。

$$
\begin{aligned}
r_{A}^{i}= & \sum_{B}\left(\beta^{i} \mu^{i}\right)_{A B}\left(\beta^{i} \mu^{i}\right)_{B A}+\sum_{B}\left(\gamma^{j} \mu^{i}\right)_{A B} \\
& +\left(\gamma^{i} \mu^{j}\right)_{A B}+\sum_{B}\left(\bar{\delta}^{j} \mu^{i}\right)_{A B}\left(\bar{\delta}^{i} \mu^{j}\right)_{B A}
\end{aligned}
$$

円弧部材の中心角 $2 \alpha$ が $30^{\circ} \leqslant 2 \alpha \leqslant 120^{\circ}$ の場合に は, 式 (63) の第 3 項が省略できて,

$$
\begin{aligned}
r_{A}^{i} \doteqdot & \sum_{B}\left(\beta^{i} \mu^{i}\right)_{A B}\left(\beta^{i} \mu^{i}\right)_{B A} \\
& +\sum_{B}\left(\gamma^{j} \mu^{i}\right)_{A B}\left(\gamma^{i} \mu^{j}\right)_{A B}
\end{aligned}
$$

特に $0^{\circ} \leq 2 \alpha \leq 30^{\circ}$ の場合は, 第 2 項をも省略でき てつぎのごとく簡単となる。

$$
r_{A}^{i} \fallingdotseq \sum_{B}\left(\beta^{i} \mu^{i}\right)_{A B}\left(\beta^{i} \mu^{i}\right)_{B A}
$$

また 3.(2) b) の式 (42) に相当する拘束成分 $\boldsymbol{M}^{i}{ }_{A}$ の 推定值 $\stackrel{\circ}{\boldsymbol{M}}^{\boldsymbol{i}}{ }_{\boldsymbol{A}}$ は次式で与えられる。

$$
\begin{aligned}
\stackrel{\circ}{\boldsymbol{M}}^{i}{ }_{A}= & t^{i}{ }_{A}\left\{\boldsymbol{M}^{i}{ }_{A}+\sum_{B}\left(\beta^{i} \mu^{i}\right)_{B A} \boldsymbol{M}^{i}{ }_{B}\right. \\
& \left.+\sum_{B}\left(\gamma^{i} \mu^{j}\right)_{A B} \boldsymbol{M}^{j}{ }_{A}+\sum_{B}\left(\bar{\delta}^{i} \mu^{j}\right)_{B A} \boldsymbol{M}^{j}{ }_{B}\right\}
\end{aligned}
$$

ただし, $t^{i}{ }_{A}=1 /\left(1-\boldsymbol{r}_{A}{ }_{A}\right)$

以上より回転成分の概算值 $[m]$ は, 式 (61) より $T^{i}{ }_{A}$

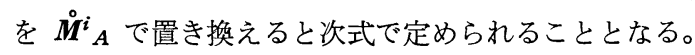

$$
\left.\begin{array}{l}
{\left[\beta^{i} m^{i}\right]_{A B}=\stackrel{\circ}{\boldsymbol{M}}_{A} \cdot\left(\beta^{i} \mu^{i}\right)_{A B}} \\
{\left[\gamma^{j} m^{i}\right]_{A B}=\stackrel{\circ}{\boldsymbol{M}}^{i}{ }_{A} \cdot\left(\gamma^{j} \mu^{i}\right)_{A B}} \\
{\left[\bar{\delta}^{j} m^{i}\right]_{A B}=\stackrel{\circ}{\boldsymbol{M}}^{i}{ }_{A} \cdot\left(\bar{\delta}^{j} \mu^{i}\right)_{A B}}
\end{array}\right\}
$$

特に拘束成分のない節点では他端の回転成分の概算值 [m] をそのまま式 (61) に適用すればよい。すなわち,

$$
\begin{aligned}
{\stackrel{\circ}{\boldsymbol{M}^{i}}}_{A}= & \sum_{\boldsymbol{B}}\left[\beta^{i} m^{i}\right]_{B A}+\sum_{B}\left[\gamma^{i} m^{j}\right]_{A B} \\
& +\sum_{B}\left[\bar{\delta}^{i} m^{j}\right]_{B A} \cdots \cdots \cdots \cdots \cdots
\end{aligned}
$$

c) 解法 節点変位のない場合は $R=R^{z}=\Delta l=0$ と なり, $M^{i}{ }_{R}=0, M^{z}{ }_{L}=0$ をらる。よって未知数は回転成 分 $m^{i}$ のみとなり, 式 (60) より容易に算出される。す なわち, 任意節点 $A$ の回転成分 $m_{A B}^{i}$ の算定法を解説 すれば, 式 (60) の右辺の大カッコの值が,

(i) 節点 $A$ の $i$ 軸に関する拘束成分 $\boldsymbol{M}^{i}{ }_{A} \cdots$ (既知)

(ii) 他端 $B$ の $i$ 軸に関する $\left(\beta^{i} m^{i}\right)_{B A} \cdots \cdots$ (末知)

(iii) $A$ 端の $j$ 軸に関する $\left(r^{i} m^{j}\right)_{A B} \cdots \cdots \cdots \cdots$ (未知)

(iv) 他端 $B$ の $j$ 軸に関する $\left(\bar{\delta}^{i} m^{j}\right)_{B A} \cdots \cdots$ (未知)

以上 4 つのモーメント量の代数和で与えられる。

よって, 実際計算の対象となるモーメント量は, $\beta^{i} m^{i}, r^{j} m^{i}$ および $\bar{\delta}^{j} m^{i}$ でいずれも式 (61) より直接算 定できる。

以上の考察からもわかるごとく，一般に曲線部材では 直線部材の場合と異なり $m^{r}$ と $m^{t}$ が従属関係にあり,

\section{図一27}
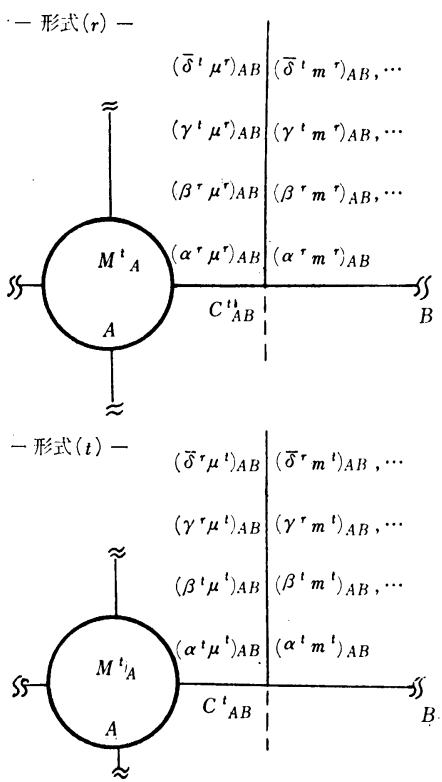

図上表示法にも特別の配慮を要する。このため著者らは 図一27 のごとき表示法を採用した。

つぎに節点変位のある場合について考察すれば以下の ごとくである。すなわち, 一般に曲線材立体構造物は構 造形式がかなり複雑であるため, その解法には節点変位 に起因するモーメント量, すなわち $M^{i}{ }_{R}$ と $M^{z}{ }_{L}$ とを そのまま未知数として解くよりも, むしろ定数とみなし て分割計算で個々の影響量を求め, 最終的に重ね合せる 慣用法によるのが有利である。この場合 $M^{i}{ }_{R}$ と $M^{z}{ }_{L}$ はいずれも定数, したがって拘束成分 $\boldsymbol{M}^{i}$ も各分割計算 を通じて定数となる。よって回転成分 $m^{i}$ の算定法は節 点変位のあるなしにかかわらず，一貫して式 (61) を使 ってよく, 以下に計算例を用いてその操作骨子を解説す る。

d) 計算例 -4 図一28 に示す 3 主桁 2 スパンの円 弧格子桁の解析を行なえば, 以下のごとくである。本例

图-28

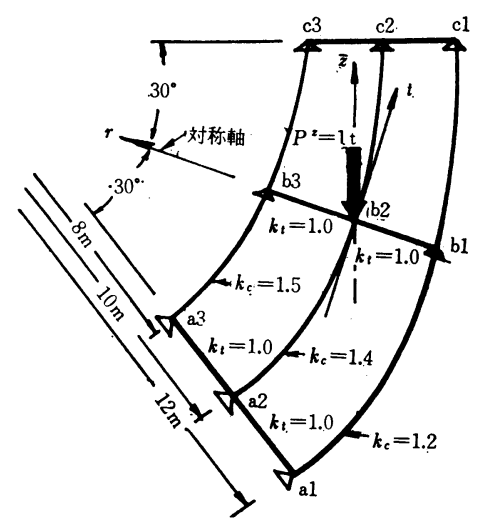


では対称条件より節点 $a i$ と節点 $c i(i=1,2,3)$ の回転 成分にはつぎの関係式が成立する。

$\left(\alpha^{r} m^{r}\right)_{a i}=-\left(\alpha^{r} m^{r}\right)_{c i},\left(\alpha^{t} m^{t}\right)_{a i}=\left(\alpha^{t} m^{t}\right)_{c i}$

$\left(\beta^{r} m^{r}\right)_{a i}=-\left(\beta^{r} m^{r}\right)_{c i}, \quad\left(\beta^{t} m^{t}\right)_{a i}=\left(\beta^{t} m^{t}\right)_{c i}$

$\left(r^{t} m^{r}\right)_{a i}=\left(r^{t} m^{r}\right)_{c i}, \quad\left(r^{r} m^{t}\right)_{a i}=-\left(r^{r} m^{t}\right)_{c i}$

$\left(\bar{\delta}^{t} m^{r}\right)_{a i}=\left(\bar{\delta}^{t} m^{r}\right)_{c i}, \quad\left(\bar{\delta}^{r} m^{t}\right)_{a i}=-\left(\bar{\delta}^{r} m^{t}\right)_{c i}$

これらの関係諸式を用うれば, 節点 $a i, b i$ 側半分だけ を計算すればよく,さらに構造形式と載荷条件より, 明 らかに形式 $(r)$ と形式 $(t)$ との組み合せを採用すれば よい。さてかかる節点変位のある構造物では演算をつぎ の 2 段階に分けて行なう必

図-29

要がある。

(i) 第 1 段階 : 所定の 荷重を加え, 節点 $b 2$ の $z$ 方向の変位を零に拘束した 状態で，バランス計算を行 なう。この場合の端モーメ ントおよび節点 $b 2$ の支点

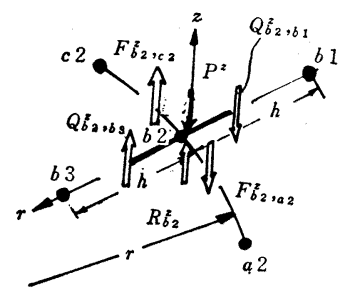

反力をそれぞれ $M^{i}{ }_{0}$ および $R_{b_{2}}$ とすれば, 節点荷重 ゆえ $M^{i}{ }_{0}(i=r, t)$ は零となり, $R_{b_{2}}^{z}$ はつぎの式 (69) より $R_{b_{2}}^{z}=\boldsymbol{P}^{z}=1.00(t)$ と算出される。 $R_{b_{2}}^{z}$ は 図一29 より次式で与えられる ${ }^{14)}$ 。

$$
R_{b_{2}}^{z}=F_{b_{2}, a_{2}}^{z}-F_{b_{2}, c_{2}}^{z_{1}}+Q_{b_{2}, b_{1}}^{z_{1}}-Q_{b_{2}, b_{3}}^{z_{2}}+\boldsymbol{P}^{z}
$$

ここに， $F^{z}$ および $Q^{z}$ はそれぞれ円弧および直線ば りの材端に働く端せん力で文献 14）よりつぎのごとく 求められる。

$$
\begin{aligned}
F_{b_{2}, a_{2}}^{z}= & \left\{\left(M_{b_{2}, a_{2}}^{r}+M_{a_{2}, b_{2}}^{r}\right) \cot \alpha\right. \\
& \left.-\left(M_{a_{2}, b_{2}}^{t}-M_{b_{2}, a_{2}}^{t}\right)\right\} / 2 r \\
F_{b_{2}, c_{2}}^{z}= & \left\{\left(M_{b_{2}, c_{2}}+M_{c_{2}, b_{2}}^{r}\right) \cot \alpha\right. \\
& \left.-\left(M_{b_{2}, c_{2}}^{t}-M_{c_{2}, b_{2}}\right)\right\} / 2 r \\
Q_{b_{2}, b_{1}}^{z}= & -\left(M_{b_{2}, b_{1}}^{t}+M_{b_{1}, b_{2}}\right) / h \\
Q_{b_{2}, b_{3}}^{z}= & -\left(M_{b_{2}, b_{3}}^{t}+M_{b_{3}, b_{2}}^{t}\right) / h
\end{aligned}
$$

（ii）第 2 段階 : 荷重を除き, 節点 $b 2$ に $z$ 軸方向の 変位 $\Delta_{{ }^{2}}{ }_{2}=-100$ を与えたときの影響を求める。このと き各部材に生ずる部材角成分は，つぎのごとく算出され る。

形式 $(r)$; 表一6 より円弧ばり $a 2, b 2$ に対しては :

$$
\begin{aligned}
\left(M_{R}^{r}\right)_{a_{2}, b_{2}} & =\left(M_{R}^{r}\right)_{b_{2}, a_{2}}=-5.480 \times 1.4 \times\left(\frac{+100}{10}\right) \\
& =-76.7
\end{aligned}
$$

形式 $(t)$; 表一6より, 円弧ばり $a 2, b 2$ に対しては :

$$
\begin{aligned}
\left(M^{t}\right)_{a_{2}, b_{2}} & =-\left(M^{t}\right)_{b_{2}, a_{2}} \\
& =2.969 \times 1.4 \times\left(\frac{+100}{10}\right)=41.6
\end{aligned}
$$

直線ばり $b 1, b 2$ に対しては：

$$
\begin{aligned}
\left(M_{R}^{t}\right)_{b_{1}, b_{2}} & =\left(M^{t}\right)_{b_{2}, b_{1}} \\
& =-6 \times 1.0 \times\left(-\frac{100}{2}\right)=300.0
\end{aligned}
$$

直線ばり $b 2, b 3$ に対しては：

$$
\begin{aligned}
\left(M^{t}\right)_{b_{2}, b_{3}} & =\left(M^{t}\right)_{b_{3}, b_{2}} \\
& =-6 \times 1.0 \times\left(\frac{100}{2}\right)=-300.0
\end{aligned}
$$

ただし, 円弧ばりの部材角成分の諸係数 $\varepsilon^{r}{ }_{A}, \varepsilon^{t}{ }_{A}$ は 半開角 $\alpha=30^{\circ}, \kappa_{1}=0.5, \kappa_{2}=0$ より，それぞれ $\varepsilon^{r}{ }_{A}=$ $-5.480, \varepsilon^{t}{ }_{A}=+2.969$ となる ${ }^{14)}$ 。

以上より外力モーメント $\bar{M}^{i}{ }_{A}=0$ および固定端モー メント $C^{i}{ }_{A B}=0$ を考慮すれば, 式 (61) より各節点の 拘束成分がただちに算定され，次值となる。

$$
\begin{aligned}
& \boldsymbol{M}_{a_{2}}^{r}=-76.7, \boldsymbol{M}_{b_{2}}=-76.7+76.7=0 \\
& \boldsymbol{M}_{b_{3}}^{t}=-\boldsymbol{M}_{b_{1}}=-300.0 \\
& \boldsymbol{M}_{b_{2}}^{t}=-41.6-41.6=-83.2
\end{aligned}
$$

一方, 円弧ばりおよび連結部材としての直線部材の形 状項 ${ }^{14)}$ はそれぞれ $\alpha^{r}{ }_{A}=3.647, \beta^{r}{ }_{A}=2.080, r^{r}{ }_{A}=$ $-0.962, \delta^{r}{ }_{A}=0.057, \alpha^{t}{ }_{A}=2.352, \beta^{t}{ }_{A}=-1.829, \gamma^{t}{ }_{A}=$ $-0.962, \delta^{t}{ }_{A}=-0.057$ および $\alpha^{r}{ }_{A}=\alpha^{t}{ }_{A}=\mathrm{G} J_{r} / h E K_{0}$ $=2, \beta^{r}{ }_{A}=\beta^{t}{ }_{A}=-G J_{r} / h E K_{0}=-2$ であり, これより回 転係数が以下のごとく算定される。

形式 $(r)$; 節点 $a 1$ で :

$$
\begin{aligned}
& \sum \alpha^{r} k_{r}=3.647 \times 1.2+2 \times 1.0=6.3764 \\
& \mu^{r} a_{1, b_{1}}=-1.2 / 6.3764=-0.1882 \\
& \mu_{a_{1}, a_{2}}=-1.0 / 6.3764=-0.1568
\end{aligned}
$$

形式 $(t)$; 節点 $a 1$ で :

$\Sigma \alpha^{t} k_{t}=2.352 \times 1.2+4 \times 1.0=6.8224$

$$
\begin{aligned}
& \mu^{t}{ }_{a_{1}, b_{1}}=-1.2 / 6.8224=-0.1759 \\
& \mu_{a_{1}, a_{2}}^{t}=-1.0 / 6.8224=-0.1466
\end{aligned}
$$

\section{（以下省略）}

よって $\alpha^{i} \mu^{i}, \beta^{i} \mu^{i}, r^{j} \mu^{i}$ および $\bar{\delta}^{j} \mu^{i}(i=r, j=t ; i=$ $t, j=r)$ は単に $\mu^{i}$ 值をそれぞれ $\alpha^{i}, \beta^{i}, r^{j}$ および $\delta^{j}$ 倍したものであり，いずれも各節点で被乗数一定の計算 にて一挙に算定できる（図一30 (a)，(b) 参照)。

つぎに各節点の拘束成分の推定值 $\dot{M}^{\boldsymbol{z}}{ }_{\boldsymbol{A}}$ を算出する。 まず式（64）および式（66）によれば $t^{i}$ はそれぞれ，

$$
\begin{aligned}
& t_{b_{3}}^{t} \fallingdotseq 1.26, t^{t}{ }_{b 2} \fallingdotseq 1.15, t^{t} b_{1} \fallingdotseq 1.21 \\
& t^{t}{ }_{a 2} \fallingdotseq 1.19, t^{r}{ }_{a 2} \fallingdotseq 1.17
\end{aligned}
$$

よって式 (66) より所要の推定值 $\dot{M}^{i}{ }_{\boldsymbol{A}}$ がつぎのごと く求められる。

$$
\begin{aligned}
\stackrel{\circ}{\boldsymbol{M}}_{b_{3}}= & 1.26\{-300+(-0.1372)(-83.2)\} \\
\fallingdotseq & -363.6 \\
\stackrel{\circ}{\boldsymbol{M}}_{b_{2}}= & 1.15\{-83.2+(-0.1808)(-300) \\
& +(-0.2074)(300)+2 \times(0.2268)(41.6)\} \\
\doteqdot & -83.3 \\
\stackrel{\circ}{\boldsymbol{M}}_{b_{1}}^{t}= & 1.21\{300+(-0.1372)(-83.2)\} \fallingdotseq 376.8 \\
\stackrel{\circ}{\boldsymbol{M}}_{a_{2}}^{t}= & 1.19\{41.6+(0.1756)(-83.2) \\
& +(0.1480)(-76.7)\} \fallingdotseq 18.7 \\
\stackrel{\circ}{\boldsymbol{M}}_{a_{2}}= & 1.17\{-76.7+(0.1193)(41.6)\} \fallingdotseq-83.9
\end{aligned}
$$

以上より回転成分の概算值を図一 30 (a), (b) の図上に 
図-30 (a)

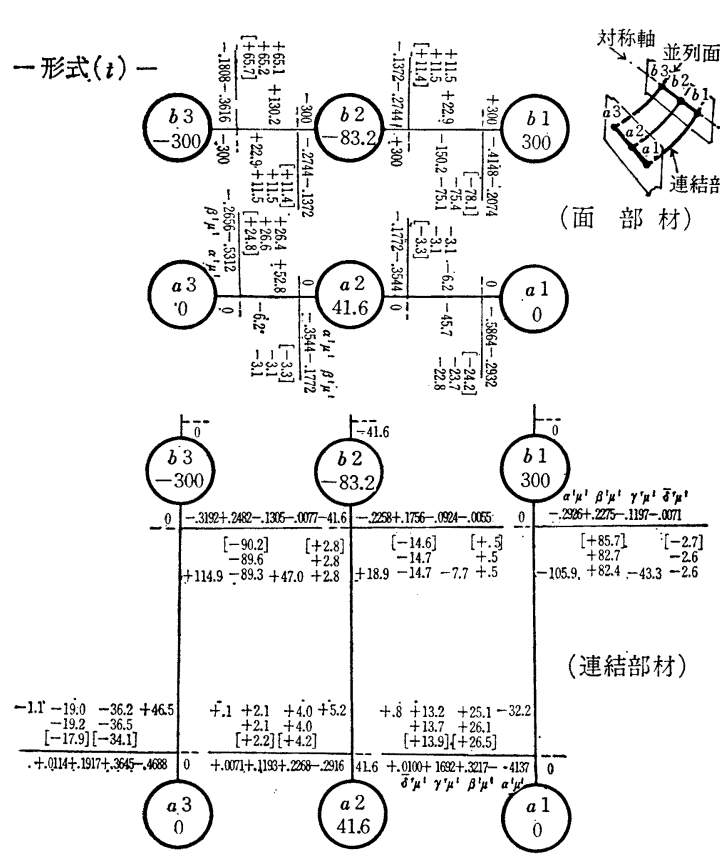

て算定すれば以下のごとくである。

形式 $(t)$; 節点 $b 3$ に抒いて: $\dot{M}^{t}{ }_{b_{3}}=-363.6$ を式 (67) に代入すれば,

$$
\begin{aligned}
& {\left[\beta^{t} m^{t}\right]_{b_{3}, a_{3}}=-363.6 \times(0.2482)=-90.2} \\
& {\left[\beta^{t} m^{t}\right]_{b_{3}, b_{2}}=-363.6 \times(-0.1808)=65.7} \\
& {\left[\tilde{\tilde{o}}^{r} m^{t}\right]_{b_{3}, a_{3}}=-363.6 \times(-0.0077)=2.8}
\end{aligned}
$$

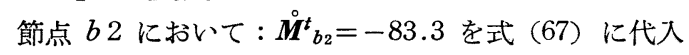
すれば,

$$
\begin{aligned}
& {\left[\beta^{t} m^{t}\right]_{b_{2}, b_{3}}=-83.3 \times(-0.1372)=11.4} \\
& {\left[\beta^{t} m^{t}\right]_{b_{2}, a_{2}}=-83.3 \times(0.1756)=-14.6} \\
& {\left[\beta^{t} m^{t}\right]_{b_{2}, b_{1}}=-83.3 \times(-0.1372)=11.4} \\
& {\left[\bar{\delta}^{r} m^{t}\right]_{b_{2}, a_{2}}=-83.3 \times(-0.0055)=0.5}
\end{aligned}
$$

節点 $b 1$ に扔いて : $\dot{M}^{t}{ }_{b_{1}}=376.8$ を式 (67) に代入す れば,

$$
\begin{aligned}
& {\left[\beta^{t} m^{t}\right]_{b_{1}, a_{1}}=376.8 \times(0.2275)=85.7} \\
& {\left[\beta^{t} m^{t}\right]_{b_{1}, b_{2}}=376.8 \times(-0.2074)=-78.1} \\
& {\left[\bar{\delta}^{r} m^{t}\right]_{b_{1}, a_{1}}=376.8 \times(-0.0071)=-2.7}
\end{aligned}
$$

節点 $a 2$ において : $\stackrel{\circ}{\boldsymbol{M}}^{t}{ }_{a 2}=18.7$ を式 (67) に代入す れば,

$$
\begin{aligned}
& {\left[\beta^{t} m^{t}\right]_{a_{2}, b_{2}}=18.7 \times(0.2268)=4.2} \\
& {\left[\beta^{t} m^{t}\right]_{a_{2}, a_{1}}=18.7 \times(-0.1772)=-3.3} \\
& {\left[\gamma^{r} m^{t}\right]_{a_{2}, b_{2}}=18.7 \times(+0.1193)=2.2} \\
& {\left[\beta^{t} m^{t}\right]_{a_{2}, a_{3}}=18.7 \times(-0.1772)=-3.3}
\end{aligned}
$$

節点 $a 3$ において:

$$
\begin{gathered}
\dot{M}_{a_{3}}=\underset{\boldsymbol{B}}{\boldsymbol{B}}\left[\beta^{t} m^{t}\right]_{B, a_{3}}+\sum_{\boldsymbol{B}}\left[\gamma^{r} m^{t}\right]_{a_{3}, \boldsymbol{B}}+\sum_{\boldsymbol{B}}\left[\bar{\delta}^{r} m^{t}\right]_{B, a_{3}} \\
=(-90.2-3.3)+(0)+(0)=-93.5 \text { より,}, \\
{\left[\beta^{t} m^{t}\right]_{a_{3}, b 3}=-93.5 \times(0.3645)=-34.1}
\end{gathered}
$$

图-30 (b)

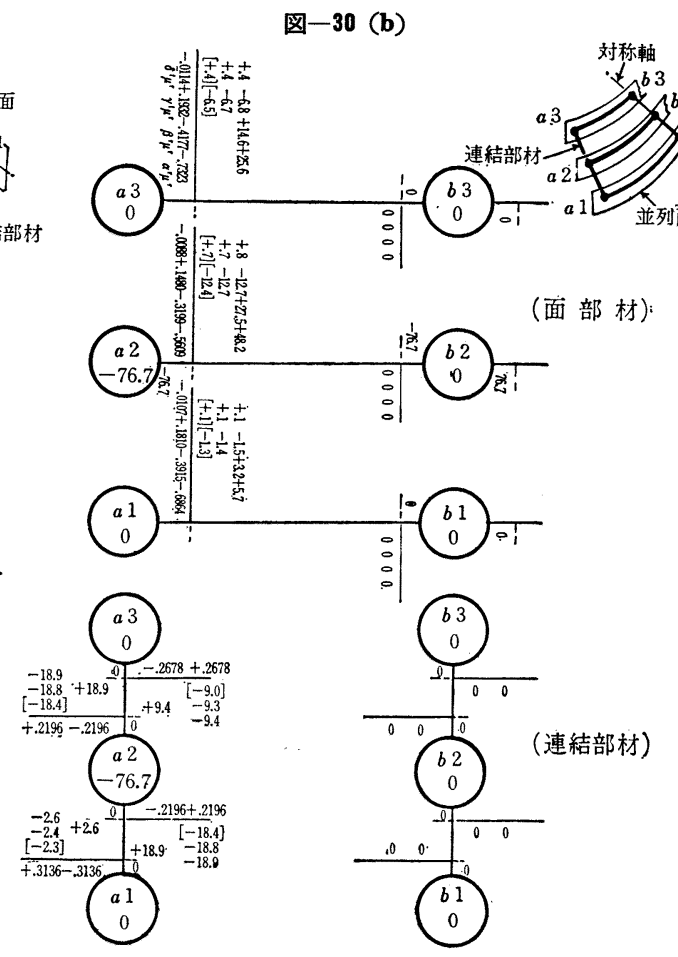

$$
\begin{aligned}
& {\left[\beta^{t} m^{t}\right]_{a_{3}, a_{2}}=-93.5 \times(-0.2656)=24.8} \\
& {\left[r^{r} m^{t}\right]_{a_{3}, b_{3}}=-93.5 \times(0.1917)=-17.9}
\end{aligned}
$$

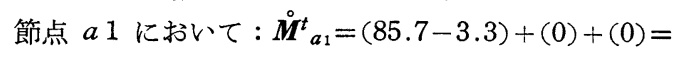
82.4 より,

$$
\begin{aligned}
& {\left[\beta^{t} m^{t}\right]_{a_{1}, b_{1}}=82.4 \times(0.3217)=26.5} \\
& {\left[\beta^{t} m^{t}\right]_{a_{1}, a_{2}}=82.4 \times(-0.2932)=-24.2} \\
& {\left[r^{r} m^{t}\right]_{a_{1}, b_{1}}=82.4 \times(0.1692)=13.9}
\end{aligned}
$$

形式 $(r)$; 節点 $a 2$ において $\stackrel{M}{\boldsymbol{M}}^{r}{ }_{a_{2}}=-83.9$ を式 (67) に代入すれば,

$$
\begin{aligned}
& {\left[r^{t} m^{r}\right]_{a_{2}, b_{2}}=-83.9 \times(0.1480)=-12.4} \\
& {\left[\beta^{r} m^{r}\right]_{a_{2}, a_{1}}=-83.9 \times(0.2196)=-18.4} \\
& {\left[\bar{\delta}^{t} m^{r}\right]_{a_{2}, b_{2}}=-83.9 \times(-0.0088)=0.7} \\
& {\left[\beta^{r} m^{r}\right]_{a_{2}, a_{3}}=-83.9 \times(0.2196)=-18.4}
\end{aligned}
$$

節点 $a 3$ に打いて :

$$
\begin{gathered}
\dot{\boldsymbol{M}}_{a_{3}}^{r}=\sum_{B}\left[\beta^{r} m^{r}\right]_{B, a_{3}}+\sum_{B}\left[r^{t} m^{r}\right]_{a_{3}, B}+\sum_{B}\left[\bar{\delta}^{t} m^{r}\right]_{B, a_{3}}= \\
(-18.4)+(-17.9)+(2.8)=-33.5 \text { より, } \\
{\left[r^{t} m^{r}\right]_{a_{3}, b_{3}}=-33.5 \times(0.1932)=-6.5} \\
{\left[\beta^{r} m^{r}\right]_{a_{3}, a_{2}}=-33.5 \times(0.2678)=-9.0} \\
{\left[\bar{\delta}^{t} m^{r}\right]_{a_{3}, b_{3}}=-33.5 \times(-0.0114)=0.4}
\end{gathered}
$$

節点 $a 1$ において :

$$
\begin{gathered}
\stackrel{\circ}{\boldsymbol{M}}_{a_{1}}^{r}=(-18.4)+(13.9)+(-2.7)=-7.2 \text { より, } \\
{\left[\gamma^{t} m^{r}\right]_{a_{1}, b_{1}}=-7.2 \times(0.1810)=-1.3} \\
{\left[\beta^{r} m^{r}\right]_{a_{1}, a_{2}}=-7.2 \times(0.3136)=-2.3} \\
{\left[\bar{\delta}^{t} m^{r}\right]_{a_{1}, b_{1}}=-7.2 \times(-0.0107)=0.1}
\end{gathered}
$$

節点 $b 1, b 2$ および節点 $b 3$ において : 対称軸上の節 点であるゆえ $m^{r}=0$ より, 当然 $\left[m^{r}\right]$ もすべて零とな る。 


\begin{tabular}{|c|c|c|c|c|c|c|c|c|c|c|c|c|c|c|c|c|c|}
\hline 材 & $a 1, b 1$ & $a 1, a$ & $a 2, a$ & $a 2$, & $3 \mid a 2, b 2$ & $2 \mid a 3, a 2$ & $a 3, b$ & $3 b 1, a 1$ & $b 1, c 1$ & $1 b 1, b 2$ & $2 b 2, b 1$ & $b 2, b 3$ & $3 b 2, a 2$ & $b 2, c 2$ & $b 3, b 2$ & $b 3, a 3$ & $\overline{b 3, c 3}$ \\
\hline$M_{1}$ & 16.3 & -16.3 & 16.3 & 9.5 & -25.9 & -9.5 & 9.4 & $\mid-39.3$ & 39.3 & 0 & 0 & 0 & -41.4 & 41.4 & 0 & 60.5 & -60.5 \\
\hline$M_{0}^{r}+\omega M_{1}^{r}$ & 0.041 & -0.041 & 0.041 & 0.02 & $4 \mid-0.064$ & -0.024 & 0.02 & -0.097 & 0.097 & 0 & 0 & 0 & -0.102 & 0.102 & 0 & 0.150 & -0.150 \\
\hline$M_{1}^{t}$ & 48.7 & $\mid-48.8$ & -29.0 & \begin{tabular}{|l|}
20.2 \\
\end{tabular} & 9.0 & 49.7 & -49.6 & $\mid-80.7$ & 0.7 & 161.3 & 247.8 & -212. & -17.9 & -17.9 & -158 & 79.1 & 79.1 \\
\hline$M_{0}{ }^{t}+\omega M_{1}{ }^{t}$ & 0.121 & -0.121 & -0.072 & 0.050 & 0.022 & 0.123 & -0.123 & -0.200 & -0.200 & $\begin{array}{ll}0 & 0.399\end{array}$ & $\begin{array}{l}9 \\
9\end{array}$ & -0.525 & $5-0.04$ & -0.044 & $4-0.392$ & 0.196 & 0.196 \\
\hline
\end{tabular}

つぎに上記算出の概算值 $\left[m^{i}\right]$ を用いて $m^{i}$ の第 1 次 近似值を求めれば, 形式 $(t)$ の節点 $a 3$ では,

$$
\begin{aligned}
& \sum_{B}\left(\beta^{t} m^{t}\right)_{B, a_{3}}=-90.2-3.3=-93.5 \\
& \sum_{B}\left(r^{t} m^{r}\right)_{a_{3}, B}=-6.5,{\underset{B}{B}}^{\left(\bar{\delta}^{t} m^{r}\right)_{B, a_{3}}=0}
\end{aligned}
$$

および $\boldsymbol{M}_{a_{3}}^{t}=0$ より式 (61) の $T^{t}{ }_{a_{3}}$ の值として,

$T^{t}{ }_{a_{3}}=0-93.5-6.5+0=-100.0$ をうる。

よって式 (61)より,

$\left(\beta^{t} m^{t}\right)_{a 3, b 3}=-100.0 \times(0.3645)=-36.5$

$\left(\beta^{t} m^{t}\right)_{a_{3}, a_{2}}=-100.0 \times(-0.2656)=26.6$

$\left(r^{r} m^{t}\right)_{a_{3}, b_{3}}=-100.0 \times(0.1917)=-19.2$

以下同様なバランス計算を節点ごとに行ない。各值が 収束するまで反復する。必要な精度内に各值が収まれば 式 $(58 \mathrm{a}) ，(58 \mathrm{~b})$ より端モーメント $M^{i}{ }_{1}$ が算出され結 果を表一8 に列記した。

ここで本第 2 段階における節点 $b 2$ の支点反力 $R^{z}{ }_{b_{2}}$ を式 (69) より算定すれば次値をうる。

$$
R_{b_{2}}^{z}=-404.04
$$

(iii) 合成計算: 第 2 段階の補正係数を $\omega$ とすれば, $\omega$ に関してつぎの条件式が成立する。

(第 1 段階の $R_{b_{2}}^{z}$ ) $+\omega \times\left(\right.$ 第 2 段階の $R_{b_{2}}^{z}$ ) $=0$;

$$
1-404.04 \omega=0
$$

ゆえに, $\omega=2.475 \times 10^{-3}$

よって所要の端モーメント $M^{i}(i=r, t)$ は, 最終的に $M^{i}=M^{i}{ }_{0}+\omega M^{i}{ }_{1}$ で与えられ, 結果のみを表一8 亿算出 表示した。

\section{（3）形式（II）の立体構造物}

a）解法 回転成分の算定, および概算値の推定に 必要な諸公式はすでに 4.(2)a), b) で一般的に求めてい るので，直交固定座標を規準とする本形式においては， 単に式 (59) (68) の添字 $i, j$ をそれぞれ $x, y$ また は $y, x$ に変ればよい。この場合, 式内容はまったく同 一であるので解法骨子は，これらの変換を考慮して形式 （I）の方法をそのまま踏襲すればよく，以下にその大網 を簡単な計算例を用いて概説する。

b) 計算例一 5 図一 31 に示す立体ラーメンの解析 を行なえばつぎのとおりである。

（i ） 準備計算: 円弧部材の半開角 $\alpha=30^{\circ}, \kappa_{1}=0.5$, $\kappa_{2}=0$ に対して形状項 ${ }^{14)}$ は $\alpha^{x}{ }_{A}=1.843, \beta^{x}{ }_{A}=-1.843$, $r^{x}{ }_{A}=\delta^{x}{ }_{A}=0.080, \alpha^{y}{ }_{A}=4.156, \beta^{y}{ }_{A}=2.066, r^{y}{ }_{A}=-$ $\delta^{y}{ }_{A}=0.080$ となり, これより各節点の回転係数が, 式 (62) より図一32 (a)，(b) のごとく求められる。ただし $\left(G J / h E K_{0}\right)_{a_{1}, b_{1}}=0.8$ とする。
图-31

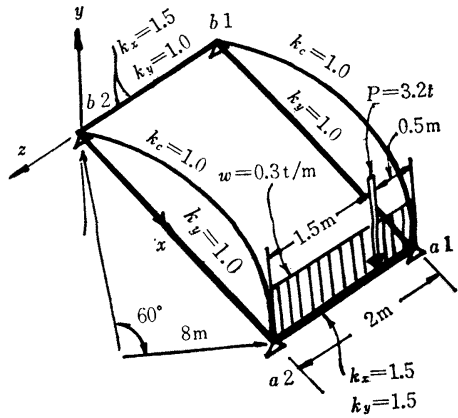

一方, 固定端モーメントは荷重条件より,

$$
\begin{aligned}
C_{a_{1}, a_{2}}^{x} & =0.3 \times 2^{2} / 12+3.2 \times 1.5^{2} \times 0.5 / 2^{2} \\
& =1.0(\mathrm{t} \cdot \mathrm{m})=10(\mathrm{t} \cdot 10 \mathrm{~cm}) \\
C^{x}{ }_{a_{2}, a_{1}} & =-0.3 \times 2^{2} / 12-3.2 \times 1.5 \times 0.5^{2} / 2^{2} \\
& =-0.4(\mathrm{t} \cdot \mathrm{m})=-4(\mathrm{t} \cdot 10 \mathrm{~cm})
\end{aligned}
$$

よって式 (61) より節点 $a 1, a 2$ の $\boldsymbol{M}^{x}$ がそれぞれ $\boldsymbol{M}^{\boldsymbol{x}}{ }_{a_{1}}=10, \boldsymbol{M}^{\boldsymbol{x}}{ }_{a_{2}}=-4$ なる值となり，また式 (65) より 項比が $\boldsymbol{r}^{x}{ }_{a_{1}}=\boldsymbol{r}^{x}{ }_{a 2} \fallingdotseq 0.214$ と求められるゆえ, 式 (66) より拘束成分の推定值がそれぞれ，下記のごとくえられ る。

$$
\text { 図-32(a) }
$$

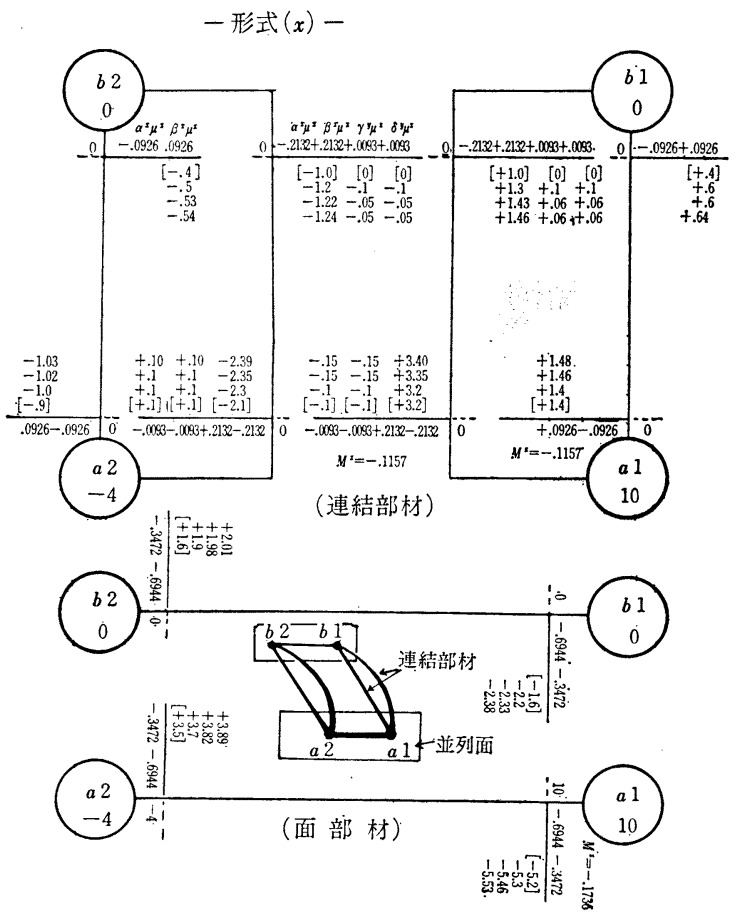




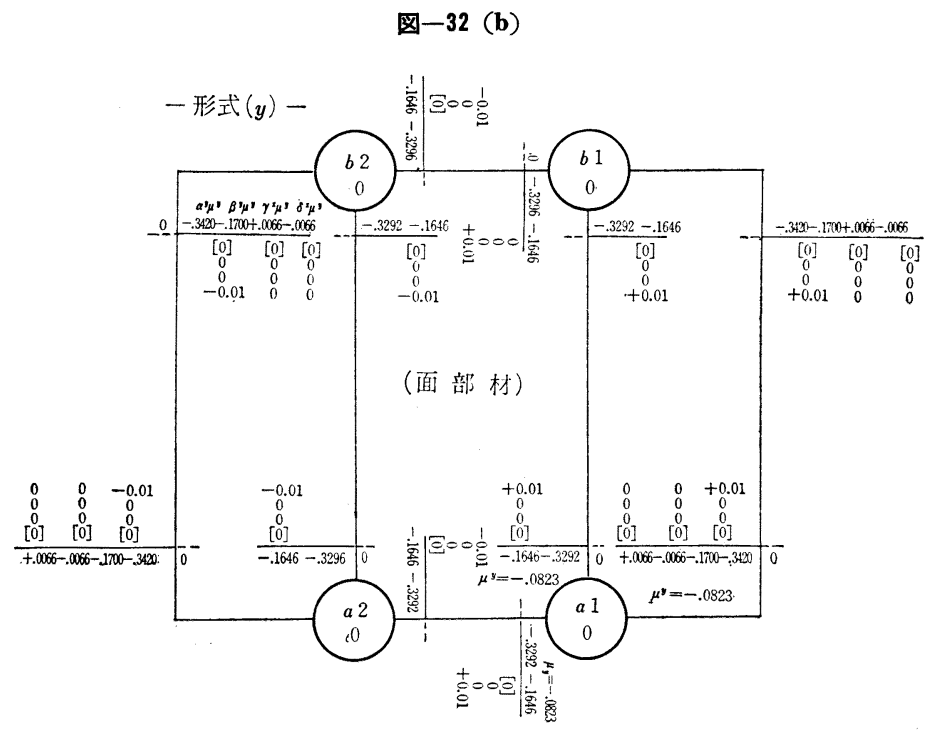

$\left(\bar{\delta}^{y} m^{x}\right)_{a 2, b 2}=-10.6 \times(-0.0093)=0.1$ 以下同様にして節点ごとに回転成分の 近似值を求め, 各值が収束するまで反復 する。

注 : 節点 $a 1, b 1$ 亿連なる円弧部材と 直線部材の区別を添字 $\overparen{a 1, b 1}$ と $\overline{a 1, b 1}$ を用いて示すものとする。

\section{5. 結語}

すでに緒言でも述べたごとく在来の Kani 法は適用範囲がきわめて狭く, わ ずかに直線部材で構成されるラーメンに 限られている。そこで著者らはその打開 策としてモーメント量の基本定義を一般 化し, 回転角に対応する回転成分 $m=$ $E K \theta$ と部材角および部材伸縮にそれぞ れ対応する部材角成分 $M_{R}$ および伸縮

$$
\stackrel{\circ}{\boldsymbol{M}}^{x}{ }_{a 1} \fallingdotseq 15, \stackrel{\circ}{\boldsymbol{M}}^{x}{ }_{a 2} \fallingdotseq-10
$$

(ii) バランス計算 (図一32 (a), (b) 参照)：まず式 (67) を用いて 各節点の回転成分の 概算值 $\left[m^{i}\right]$ を算定 する。すなわち，

形式 $(x)$; 節点 $a 1$ において: $\stackrel{\circ}{\boldsymbol{M}}^{x}{ }_{11}=15$ を式 (67) に代入して,

$$
\begin{aligned}
& {\left[\beta^{x} m^{x}\right]_{a 1, a 2}=15 \times(-0.3472)=-5.2} \\
& {\left[\beta^{x} m^{x}\right]_{a 1, b 1}=15 \times(0.0926)=1.4} \\
& {\left[\beta^{x} m^{x}\right]_{a 1, b 1}=15 \times(0.2132)=3.2} \\
& {\left[r^{y} m^{x}\right]_{a 1, b 1}=15 \times(-0.0093)=-0.1} \\
& {\left[\bar{\delta}^{y} m^{x}\right]_{a 1, b 1}=15 \times(-0.0093)=-0.1}
\end{aligned}
$$

節点 $a 2$ において ${\stackrel{M}{a_{2}}}^{x}=-10$ を式 (67) に代入し $\tau$,

$$
\begin{aligned}
& {\left[\beta^{x} m^{x}\right]_{a 2, a 1}=-10 \times(-0.3475)=3.5} \\
& {\left[\beta^{x} m^{x}\right] \overline{a, b 2}=-10 \times(0.0926)=-0.9} \\
& {\left[\beta^{x} m^{x}\right]_{a, b 2}=-10 \times(0.2132)=-2.1} \\
& {\left[\gamma^{y} m^{x}\right]_{a 2, b 2}=-10 \times(-0.0093)=0.1} \\
& {\left[\bar{\delta}^{y} m^{x}\right]_{a 2, b 2}=-10 \times(-0.0093)=01}
\end{aligned}
$$

\section{(以下省略)}

つぎに, 以上の諸值を用いて通常のバランス計算に移 行する。すなわち, 形式 $(x)$;

節点 $a 2$ において :

$$
\begin{aligned}
& \boldsymbol{M}^{\boldsymbol{x}}{ }_{a_{2}}=-4, \underset{B}{\boldsymbol{B}}\left(\beta^{x} m^{\boldsymbol{x}}\right)_{B, a_{2}}=-6.6 \\
& \sum_{B}\left(\gamma^{x} m^{y}\right)_{a 2, B}=0, \sum_{B}\left(\bar{\delta}^{x} m^{y}\right)_{B, a_{2}}=0
\end{aligned}
$$

より, 式 (61) の $T^{x} a_{2}$ の值 -10.6 をえ, 式 (61)よ り, 同節点の回転成分の第 1 次近似值がつぎのごとく求 められる。

$$
\begin{aligned}
& \left(\beta^{x} m^{x}\right)_{a 2, a 1}=-10.6 \times(-0.3472)=3.7 \\
& \left(\beta^{x} m^{x}\right)_{a 2, b 2}=-10.6 \times(0.0926)=-1.0 \\
& \left(\beta^{x} m^{x}\right)_{a 2, b 2}=-10.6 \times(0.2132)=-2.3 \\
& \left(\gamma^{y} m^{x}\right)_{a 2, b 2}=-10.6 \times(-0.0093)=0.1
\end{aligned}
$$

成分 $M_{L}$ を新たに導入して，任意形状部材をもつ平面 ラーメンはいらにおよばず，曲線部材をもつ立体ラーメ ンに対しても適用可能なるごとく拡張した。すなわち， 2. では平面ラーメンを対象に選び，まず上述の $m, M_{R}$ および $M_{L}$ の各成分の算定式を誘導し，ついでかかる 諸成分を解析の基礎とする新しい試索算法である“Kani 抎張法”の案出を試みた。特に伸縮部材を有する平面ラ ーメンについては剛棒を使用して伸縮部材に連なる節点 の変位のみを一定量に拘束したまま解析を進める一般解 法と，これらの変位をすべて未知数と考えてバランス計 算を行なら特殊解法とを提案した。前者はいかなる形式 の構造物にも適用できる普遍性と実用性とを合せもち， しかも収斂性がよく，特に図一6(c), (d), (e) のごとき 多層ラーメンに対しては Cross 法と比較して相当数の 演算段階を短縮でき，したがってそれだけ労力を節減で きる特色をもっている。後者は演算を 1 段階のみで行な いうるので補正計算の手間はまったく不要となり, 演算 量がはるかに縮小され，特に図一9 (a)，(b) のごとき特 殊な形式のラーメンに対して威力を発揮する。

一般に試索算法にあってはあらかじめ収束値に近い概 算值が推定できれば収㪘性の飛躍的な促進が期待されう るので, この目的のために等比級数に基づく概算值推定 法を別に考案した。すなわち，2.(4)に述べたごとく本 推定法を用うれば，簡単な予備計算を施すだけで収束值 にきわめて近い概算值が算定でき，したがってバランス 計算回数を大幅に短縮しうることが認められた。

つぎに 3. および 4. では直線部材で構成される立体 ラーメンおよび曲線部材をもつ立体ラーメンを対象とし て考察を行ならべく，まず構成部材を面部材と連結部材 とに分類して複雑な立体構造物を簡単かつ統一的に分解 し, ついでこの分類法に基づいて 3 軸方向に分解した変 
形成分に対応して平面と 同一定義の 3 軸方向の回転成 分, 部材角成分および伸縮成分をそれぞれ導入し, 平面 解法とまったく同一手法の試索算法の展開を可能ならし め, 図一20(a), (b) のごとき互に直交する直線材立体ラ 一メンや図一24(a), (b) に示す水平面内に曲線部材をも つ立体ラーメンや連続格子桁などに遍く適用しうるごと くした。本論文では曲線部材に円弧部材を選んだが，ク ロソイド, S 形, 対称山形, および台形などの他形状の 曲線部材をもつ立体ラーメン ${ }^{15)}$ に対しても, 著者らの誘 導したたわみ角式を用うれば，単に形状項 $\alpha_{A}, \alpha_{B}, \cdots$ と 荷重項とを変えるだけで, 同種演算による数值解析がそ のまま可能となる。節点変位のある立体ラーメンにおい ては, 図一16 のごとき多主桁 1 層多スパンラーメンを 例外とすれば $M_{R}$ 算定式がきわめて繁雑となるので, 演算にあたっては逐次一定変位を与えて重ね合せの法則 を用いて合成する慣用法を採用した。この場合末知数は 回転成分のみとなるゆえ演算操作はきわめて簡明で，バ ランス計算は短時間のうちに終了するが, 反面合成計算 を行なわなければならず，したがってこの方法は変位節 点数が比較的少ない場合任意形式の立体構造物に対する 有効な解法といえる。

以上のごとく Kani 拡張法は在来の諸解法と比較して 一般性ならびに収㪘性さらには簡便性のいずれの点にお いても優れた有用なる試索算法であり，本法を習熟すれ ば, 電子計算機を活用しての精密解法とは全然異質の分 野として個人個人が簡単な計算機器を用いて手軽にかな り複雑な構造物をも解析しうることが可能となり Cross 法や暁角分配法と類似の世界においてその価值を主張し うるものと確信する。なおぺージ数の制限もあり, 極端 に短縮したため, 細部についての説明不足, 特に例題の 省略による演算手法の解説不備により, 本論文の内容特 色ひいては真価を十分表現しえなかったことを危惧する が，くわしくは文献 11）を参照補足して頂きたく，こ こに付記して御願いする次第である。

\section{参考文献}

1) Cross, H.: Analysis of Continuous Frames by Distributing Fixed-end Moments, Proc. A.S.C.E., May, 1930

Cross, H. and Morgan, N.D. : Continuous Frames of Reinforced Concrete, J. Wily \& Sons, 1932

2) Murakami, T. : A Note on the Moment Distribution Principles, Memoirs of the Faculty of Engineering, Kyushu University, Vol. XV, No. 1, 1955

3) 吉田俊弥: 立体ラーメンの一数値解法, 土木学会論文集, 第 33 号, 昭和 31 年 4 月

Rawlings, B.: The General Moment Distribution Analysis of Space Frames, The Structural Engineer, Vol. XXXVIII, No. 6, June, 1960

4）䳡部屋福平：不静定構造物の解法に応用したる暁角分配 法, 土木学会誌, 第 21 巻. 第 1 号, 昭和 10 年 1 月

5) Grinter, L.E. : Analysis of Continuous Frames by Balancing Angle Changes, Proc. A.S.C.E., Vol. 62, September, 1936
6) Kani, G. : Die Berechnung mehrstöckiger Rahmen, Verlag, Konrad, Wittwer, Stuttgart, 1949

7) Herber, K.H. : Vereinfachung der Rahmenberechnung nach Kani und Verbesserung der Konvergenz, Die Bautecknik, 32 Jahrgang, Heft 9, September, 1955

8）Kani, G.: 多層ラーメンの数值計算法, 技報堂全書, 1961

9）山崎・太田：直線 および 円弧部材をもつ立体ラーメンの 影響線解法, 一新 Kani 法による影響線解法 (第 2 報)一, 九州大学工学集報, 第 39 巻, 第 2 号, 昭和 41 年 8 月

10) Sahmel, P.: Die Berechnung von Rahmen mit gaknickten Riegeln sowie Polygonrahmen nach dem erweiterten Iterationsverfahren von Kani, Betonund Stahlbetonbau, 56 Jahrgang, Heft 8, August, 1961

11）山䐀・太田：Kani 拡張法による伸縮部材を含まない平面 ラーメンの解法, 一Kani 拡張法 (第 1 報) 一, 九州大学 工学集報, 第 39 巻, 第 3 号, 昭和 41 年 10 月

山崎・太田 : Kani 拡張法による伸縮部材を含む平面ラー メンの解法, 一Kani 拡張法 (第 2 報)一, 九州大学工学 集報, 第 39 巻, 第 3 号, 昭和 41 年 10 月

山崎・太田：概算值を用いた Kani 拡張法による平面ラ 一メンの解法, 一Kani 拡張法 (第 3 報)一, 九州大学工 学集報, 第 39 巻, 第 4 号, 昭和 42 年 1 月 山崎・太田：Kani 拡張法による節点变位のない直線材立 体構造物の解法, 一Kani 拡張法 (第 4 報) 一, 九州大学 工学集報, 第 39 巻, 第 4 号, 昭和 42 年 1 月 山崎・太田 : Kani 拡張法による節点変位のある直線材立 体構造物の解法, 一 Kani 拡張法 (第 5 報)一, 九州大学 工学集報, 第 40 巻, 第 1 号, 昭和 42 年 3 月

山䐀・太田: Kani 拡張法による曲線材立体構造物の解 法, 一 Kani 拡張法 (第 6 報)一, 九州大学工学集報, 第 40 巻, 第 1 号, 昭和 42 年 3 月

12) Murakami, T. : Studies on Slope-Deflection Method, Memoirs os the Faculty of Engineering, Kyushu University, Vol. XIV, No. 1, 1953

13) Sahmel, P. : Beschleunigung der Konvergenz bei Berechnung von Rahmentragwerken nach Kani, Der Stahlbau, 23 Jahrgang, Heft 11, November, 1954

Zellerer, E. und Thiel, H. : Zur Frage einer Ver* kürzung der Iteration nach Kani, Die Bautecknick, 33 Jahrgang, Heft 8, August, 1956

14）山崎・太田: 円弧部材をもつラーメンの立体解析, 土木 学会論文集, 第 107 号, 昭和 39 年 7 月

15）山崎・太田・入江：面に垂直な荷重をうけるクロソイド 曲線材の立体暁角式, 第 18 回土木学会年次学術講演会講 演概要, 昭和 38 年 5 月

山崎・太田：クロソイド部材の軸面内荷重に対する “た わみ角式”, 九州大学工学集報, 第 38 巻, 第 2 号, 昭和 40 年 6 月

山崎・太田：対称山形部材をもつ立体 ラーメンの解析, 九州大学工学集報, 第 39 巻, 第 2 号, 昭和 41 年 8 月 山崎・太田・彦坂：S 形部材をもつ連続桁および ラーメ ンの立体解析, 九州大学工学集報, 第 39 巻, 第 3 号, 昭和 41 年 10 月

山崎・太田：対称台形部材に対する平面ならびに立体た たみ角式, 九州大学工学集報, 第 40 巻, 第 1 号, 昭和 42 年 3 月

Yamasaki T. and Ohta, T.: Three-Dimensional Slope-Deflection Equation of Noncoplanar Member, Proc. of the 14 th Japan National Congress for Applied Mechanics 1964, December, 1965

(1965.12.1，1966.1.31，1966.3.30・受付)

注 : 本論文は上記の順に受付けた 3 編の論文を一つにとりまとめたもの である。 